\title{
Toekomstverkenning arbeidsmarkt apothekersassistenten in de openbare apotheek
}

Citation for published version (APA):

de Grip, A., \& Vlasblom, J. D. (1999). Toekomstverkenning arbeidsmarkt apothekersassistenten in de openbare apotheek. Researchcentrum voor Onderwijs en Arbeidsmarkt, Faculteit der Economische Wetenschappen. ROA Reports No. 7 https://doi.org/10.26481/umarep.1999007

Document status and date:

Published: 01/01/1999

DOI:

10.26481/umarep.1999007

Document Version:

Publisher's PDF, also known as Version of record

\section{Please check the document version of this publication:}

- A submitted manuscript is the version of the article upon submission and before peer-review. There can be important differences between the submitted version and the official published version of record.

People interested in the research are advised to contact the author for the final version of the publication, or visit the DOI to the publisher's website.

- The final author version and the galley proof are versions of the publication after peer review.

- The final published version features the final layout of the paper including the volume, issue and page numbers.

Link to publication

\footnotetext{
General rights rights.

- You may freely distribute the URL identifying the publication in the public portal. please follow below link for the End User Agreement:

www.umlib.nl/taverne-license

Take down policy

If you believe that this document breaches copyright please contact us at:

repository@maastrichtuniversity.nl

providing details and we will investigate your claim.
}

Copyright and moral rights for the publications made accessible in the public portal are retained by the authors and/or other copyright owners and it is a condition of accessing publications that users recognise and abide by the legal requirements associated with these

- Users may download and print one copy of any publication from the public portal for the purpose of private study or research.

- You may not further distribute the material or use it for any profit-making activity or commercial gain

If the publication is distributed under the terms of Article $25 \mathrm{fa}$ of the Dutch Copyright Act, indicated by the "Taverne" license above, 


\section{Toekomstverkenning arbeidsmarkt apothekersassistenten in de openbare apotheek}

ROA-R-1999/7

Andries de Grip

Jan Dirk Vlasblom

Researchcentrum voor Onderwijs en Arbeidsmarkt

Faculteit der Economische Wetenschappen en Bedrijfskunde Universiteit Maastricht

Maastricht, mei 1999 
ISBN 90-5321-258-2

Sec98.165/JDV 


\section{Inhoud}

Bladzijde

Voonwoord

1 Inleiding

2 De arbeidsmarkt voor apothekersassistenten

2.1 Inleiding

2.2 Werkenden

2.3 Niet-participerenden 9

2.4 Instroom van gediplomeerde apothekersassistenten $\quad 10$

$\begin{array}{ll}2.5 \text { Uitstroom van werkenden } & 16\end{array}$

3 Toekomstige ontwikkelingen op de arbeidsmarkt 21

$\begin{array}{ll}3.1 \text { Inleiding } & 21\end{array}$

$\begin{array}{ll}3.2 \text { Stromen op de arbeidsmarkt } & 21\end{array}$

3.3 Ontwikkelingen in het aantal receptregels 23

3.4 Vraag naar apothekersassistenten in de openbare apotheken 25

$\begin{array}{ll}3.5 \text { Aanbod van apothekersassistenten } & 30\end{array}$

3.6 Verwachte knelpunten op de arbeidsmarkt 33

3.7 Vergelijking met eerdere prognoses $\quad 34$

4 Gevoeligheidsanalyses $\quad 39$

4.1 Inleiding 39

4.2 Veranderingen in de uitbreidingsvraag 41

4.3 Veranderingen in de vervangingsvraag 46

4.4 Veranderingen in de instroom van schoolverlaters 48

5 Conclusies en aanbevelingen 51

5.1 Conclusies 51

5.2 Aanbevelingen voor een adequate informatievoorziening 54

$\begin{array}{ll}\text { Literatuur } & 59\end{array}$ 



\section{Voorwoord}

De komende jaren wordt er een tekort aan apothekersassistenten verwacht. Vanwege de specifieke opleiding van apothekersassistenten is het moeilijk om als er zich een tekort voordoet dit op korte termijn te verhelpen. Om tijdig maatregelen te nemen is een studie verricht die inzicht moet geven in de omvang van de in de komende jaren te venwachten tekorten. Dit rapport bevat de resultaten van deze lange-termijn studie. De onderzoekers danken dhr. E. Visser van de SBA, dhr. H.C.J. Overgaag van de KNMP en dhr. J.L. Tinke van de SFK voor hun inbreng bij de totstandkoming van dit rapport. Zij willen ook hun dank uitspreken naar de SPMA en de SFK die hen data beschikbaar hebben gesteld. De data van de SPMA zijn door dhr. A. Velthuizen in een voor het onderzoek bruikbare vorm gebracht. Allard Bruinshoofd heeft medewerking verleend bij de analyses die voor dit rapport ziin uitgevoerd. 


\section{Inleiding}

De kwaliteit van de dienstverlening in de apotheken is in belangrijke mate afhankelijk van de beschikbaarheid van goed opgeleid personeel. Omdat meer dan $70 \%$ van de werknemers in de openbare apotheken het beroep van apothekersassistent uitoefent', is de kwaliteit van de dienstverlening in de apotheken in belangrijke mate afhankelijk van de kennis en vaardigheden die apothekersassistenten gedurende hun opleiding hebben opgedaan. Daarbij gaat het niet alleen om de kwalificaties die afgestudeerde apothekersassistenten tijdens hun opleiding hebben verworven, maar ook om de kwalitatieve aansluiting tussen vraag en aanbod op het arbeidsmarktsegment voor apothekersassistenten. Een tekort op de arbeidsmarkt voor apothekersassistenten kan de kwaliteit van de dienstverlening in de apotheken emstig in gevaar brengen. Daarentegen zal een overschot op de arbeidsmarkt voor apothekersassistenten er niet direct toe leiden dat de kwaliteit van de dienstverlening vermindert. Een overschot en de daaruit voortkomende verslechterende arbeidsmarktpositie voor apothekersassistenten kan echter wel leiden tot een negatief imago van de hele beroepsgroep, met als gevolg een afnemende interesse onder scholieren voor de opleiding tot apothekersassistent. Op de langere termijn kan het dalende aantal leerlingen op de opleiding tot apothekersassistent weer leiden tot een tekort aan apothekersassistenten. Dit fenomeen staat bekend als de zogenaamde 'varkenscyclus'. Diverse segmenten van de arbeidsmarkt hebben met name vanwege de nauwe relatie tussen opleiding en beroep te kampen met een dergelijke varkenscyclus (Zie b.v. De Grip, 1988).

De situatie op de arbeidsmarkt voor apothekersassistenten lijkt mede door deze processen onderhevig te zijn aan aanzienlijke fluctuaties. In 1993 was er nog een relatief hoog percentage moeilijk vervulbare vacatures voor apothekersassistenten (MRCN, 1993, ROA, 1993b). De Stichting Bedrijfsfonds Apotheken (SBA) trachitte daarom zicht te krijgen op de oorzaken en gevolgen van het tekort aan apothekersassistenten en de te treffen beleidsmaatregelen, waaronder bijvoorbeeld het stimuleren van de herintreding van apothekersassistenten. In 1994 lijkt zich echter een omslag voor te doen naar een overschot aan apothekersassistenten: het aantal vacatures dat in 1994 gerapporteerd werd door de apothekers is slechts eenderde van het aantal dat in 1993 opgegeven werd (Zie o.a. SBA, 1995, en Linssen, 1996). Dit overschot aan apothekersassistenten lijkt sinds 1994 langzaam weer af te nemen. Deze golfbeweging lijkt zich ook te vertalen in de werkloosheidscijfers. In 1994 en 1995 is er een toename van de werkloosheid onder apothekersassistenten. Sinds 1996 is er echter een afname waar te nemen. Werden er in 1996 nog 962 apothekersassistenten door de RBA's als werkloos geregistreerd, in 1997 is dat afgenomen tot 919 . In januari 1997 lag het werk-

1. Op 1 januari 1997 waren er 15.600 personen werkzaam in de openbare apotheek: 2.319 apothekers, 11.239 apothekersassistenten en 2.042 hulpmedewerkers (SFK, 1997). Deze hulpmedewerkers die ook onder de CAO apotheken vallen, zijn geen apothekersassistenten maar bijvoorbeeld bezorger, boekhouder, schoonmaker (SBA 1997). 
loosheidspercentage daarmee op 6,4\%, net iets onder het landelijk gemiddelde van $7,0 \%$. Deze daling van de werkloosheid heeft zich voortgezet, want op 1 januari 1998 stonden er nog slechts 735 werklozen geregistreerd, waarmee het werkloosheidspercentage op $5,1 \%$ lag, nog steeds onder het landelijk gemiddelde dat $5,5 \%$ bedroeg (SFK, 1997, 1998). Ondanks de in 1993 op scholen gevoerde promotiecampagnes, die als doel hadden de instroom voor de opleiding van apothekersassistent te stimuleren, heeft de verkrapping van de arbeidsmarkt zich doorgezet. Het kan echter niet uitgesloten worden dat er grotere tekorten zouden zijn ontstaan zonder deze promotiecampagnes. Daamaast hebben de overheidsmaatregelen gericht op een beheersing van de kosten van de farmaceutische hulp een afname van de werkgelegenheid voor apothekersassistenten tot gevolg gehad (Van Rooij e.a., 1995). Dit heeft mogelijk bijgedragen aan het voorkómen van grote tekorten aan apothekersassistenten tot nu toe. Vanwege het eenmalige karakter van zowel de voorlichtingscampagne als verschillende van de overheidsmaatregelen kan bij een toenemende vraag naar apothekersassistenten een forse toename van het tekort niet uitgesloten worden.

Uit eerder door het Researchcentrum voor Onderwijs en Arbeidsmarkt (ROA) uitgevoerd onderzoek (Van Smoorenburg e.a., 1996) blijkt dat een zeer groot deel van de werkzame schoolverlaters met een opleiding tot apothekersassistent ook daadwerkelijk een baan vindt als apothekersassistent. Ook blijkt het merendeel van de schoolverlaters dat als apothekersassistent werkzaam is een opleiding tot apothekersassistent te hebben gevolgd. Om deze redenen kan de arbeidsmarkt voor apothekersassistenten getypeerd worden als een geprofessionaliseerde vakdeelmarkt. Met andere woorden, afgestudeerde apothekersassistenten ondervinden nauwelijks concurrentie van schoolverlaters van andere opleidingen bij het zoeken naar een baan als apothekersassistent, maar komen zelf ook relatief weinig terecht in andere beroepen of branches. Eén van de voordelen van de nauwe aansluiting tussen opleiding en beroep van apothekersassistenten is dat degenen die deze opleiding gaan volgen een redelijk grote mate van zekerheid hebben in welke beroepssituatie ze na het afsluiten van hun studie terechtkomen en wat er van hen verwacht wordt in de uitoefening van hun beroep. Daamaast wordt het opgebouwde menselijk kapitaal van de afgestudeerde apothekersassistenten optimaal gebruikt en hebben werkgevers een goed inzicht in de kwalificaties waarover de afgestudeerde apothekersassistenten beschikken.

De nauwe aansluiting tussen opleiding en beroep voor apothekersassistenten heeft echter ook een keerzijde. De risico's van een nauwe aansluiting tussen opleiding en beroep doen zich zowel voor bij een aanbodtekort als bij een vraagtekort van apothekersassistenten. Bij een aanbodtekort hebben werkgevers geen goede mogelijkheden om schoolverlaters met een andere opleidingsachtergrond aan te nemen. Dit impliceert dat de substitutiemogelijkheden voor werkgevers in de farmaceutische zorg bij een aanbodtekort beperkt zijn. Bij een vraagtekort zijn er voor gediplomeerde apothekersassistenten weinig mogelijkheden om een ander beroep dan apothekersassistent te vinden. Zoals reeds werd opgemerkt kan hierdoor de belangstelling voor de opleiding 
tot apothekersassistent afnemen, hetgeen op termijn weer zal leiden tot een tekortschietend aanbod. Het is daarom van groot belang de vinger aan de pols te houden bij de afstemming tussen vraag en aanbod van personeel in de apotheeksector.

Het voeren van preventief arbeidsmarktbeleid is ook van groot belang omdat het de voorkeur verdient niet te wachten met het nemen van beleidsmaatregelen tot tekorten of overschotten van apothekersassistenten zich daadwerkelijk manifesteren. Ook hier geidt dat voorkomen beter is dan genezen. Voor het voeren van een verantwoord preventief arbeidsmarktbeleid dat gebaseerd is op de verwachte ontwikkelingen en knelpunten op de arbeidsmarkt voor apothekersassistenten is het van belang om te kunnen beschikken over prognoses omtrent de vraag naar en het aanbod van apothekersassistenten. In de praktijk blijkt echter dat juist onverwachte veranderingen in het overheidsbeleid een verstorende invloed kunnen hebben op het evenwicht op de arbeidsmarkt van sterk op de kwartaire sector gerichte opleidingen (Borghans, 1991). Uit eerder onderzoek (De Grip e.a., 1994) is gebleken dat het overheidsingrijpen van zeer groot effect is op de ontwikkelingen op de arbeidsmarkt voor de zorgsector. Dit overheidsingrijpen is echter het gevolg van politieke besluitvorming, en derhalve zeer moeilijk voorspelbaar. Daarom zal in dit rapport in eerste instantie een basisscenario worden opgesteld dat gebaseerd is op de 'structurele groei' van het medicijngebruik, dat is de groei zoals die zich zal voordoen als overheidsingrijpen achterwege blijft. Vervolgens zal, in de vorm van gevoeligheidsanalyses, worden nagegaan in hoeverre de ontwik. kelingen anders zullen zijn als de groei wel door overheidsingrijpen, zoals het stimuleren van marktwerking, verminderd zal worden. Ook de gevoeligheid van de prognoses voor andere omgevingsfactoren - bijvoorbeeld de vergrijzing van de bevolking of een veranderend aanbod van schoolverlaters - zal in kaart worden gebracht. Op deze wijze wordt inzicht verkregen in de onzekerheidsmarges van de arbeidsmarktperspectieven.

De indeling van het rapport is als volgt. Voordat de prognoses worden gepresenteerd, zal eerst in hoofdstuk 2 worden stilgestaan bij de ontwikkelingen die zich de afgelopen tijd op de arbeidsmarkt voor apothekersassistenten hebben voorgedaan. Hierbij wordt een beeld geschetst van de omvang en samenstelling van de groepen werkenden en niet-participerende apothekersassistenten en de arbeidsmarktinstroom en -uitstroom. Op deze wijze wordt ook inzicht verkregen in de oorzaken en mogelijke oplossingen van knelpunten in de personeelsvoorziening. In hoofdstuk 3 worden vervolgens de op het basisscenario gebaseerde vraag- en aanbodprognoses voor de komende jaren gepresenteerd en de op basis daarvan verwachte knelpunten op de arbeidsmarkt. Tevens wordt in dit hoofdstuk een vergelijking gemaakt met eerdere prognosestudies. In hoofdstuk 4 wordt aangegeven in hoeverre de opgestelde arbeidsmarktprognoses afhangen van een aantal factoren zoals bevolkingsgroei en ontwikkelingen in medicijngebruik. Het rapport wordt besloten met een aantal conclusies in hoofdstuk 5 . In dit laatste hoofdstuk wordt ook stilgestaan bij de vraag of de huidige informatiebronnen voldoende inzicht bieden in de op de markt spelende processen. In aansluiting daarop worden enkele aanbevelingen gedaan voor een betere informatievoorziening. 


\section{De arbeidsmarkt voor apothekersassistenten}

\subsection{Inleiding}

In dit hoofdstuk zal worden stilgestaan bij de ontwikkelingen die de afgelopen tijd op de arbeidsmarkt voor apothekersassistenten zichtbaar zijn geweest. In dit hoofdstuk wordt een beeld geschetst van de verschillende groepen op de arbeidsmarkt, zoals schoolverlaters, werkenden en niet-participerenden, en in welke mate tussen deze groepen stromen optreden. Het onderscheid tussen deze stromen is van belang omdat niet alle maatregelen op dezelfde stromen invloed zullen hebben. Door cnderscheid te maken tussen deze stromen en de mogelijke effecten die de ontwikkelingen en maatregelen daarop hebben, kan een goede indruk verkregen worden van de oorzaken en mogelijke oplossingen van de knelpunten in de personeelsvoorziening in de openbare apotheek.

De gegevens die in dit hoofdstuk gepresenteerd worden, zijn afkomstig uit een aantal bronnen. Er worden data gebruikt van de Stichting Pensioenfonds Medewerkers Apotheken (SPMA). De door de SPMA verstrekte data geven inzicht in de omvang en samenstelling van het huidige personeelsbestand van gediplomeerde apothekersassistenten in de openbare apotheken. Een aantal cijfers is afkomstig uit publicaties van de Stichting Farmaceutische Kengetallen (SFK). Daarnaast zijn er gegevens gebruikt uit de Enquête Beroepsbevolking van het CBS. Deze gegevens hebben betrekking op de samenstelling van de niet-participerende potentiële beroepsbevolking die beschikt over de juiste opleiding om als apothekersassistent werkzaam te zijn, en waarschijnlijk in het verleden ook al als apothekersassistent gewerkt heeft. Als laatste zijn er gegevens gebruikt over de schoolverlaters uit de opleiding tot apothekersassistent. Deze gegevens zijn ontleend aan de schoolverlatersenquêtes van het ROA (RUBS, Registratie Uitstroom en Bestemming van Schoolverlaters). Alle gebruikte cijfers hebben betrekking op de periode tot januari 1998.

\subsection{Werkenden}

In de volgende tabellen wordt een aantal kenmerken van de werkende apothekersassistenten gepresenteerd. Tabel 2.1 geeft een beeld van de ontwikkeling van de omvang van de werkgelegenheid voor apothekersassistenten in de afgelopen jaren ${ }^{2}$. Hierbij is gekeken naar het aantal werkzame personen. Ook is aangegeven wat de lengte van de gemiddelde werkweek is, en in welke mate er in deeltijd wordt gewerkt. Deze cijfers geven geen inzicht in het bestaan van onvervulde of onvervulbare vacatures. Dat wil zeggen dat als er sprake is van een structureel tekort aan apothekersassistenten de omvang van de werkgelegenheid groter is dan de hier aangegeven aantallen.

2. De cijfers in deze en alle volgende tabellen hebben betrekking op de standcijfers op 1 januari van de aangegeven jaren. 
Tabel 2.1

Kencijfers totale werkgelegenheid apothekersassistenten, 1995 - 1998

\begin{tabular}{lccccc}
\hline & 1995 & 1996 & 1997 & 1998 & $\begin{array}{c}\text { Toename } \\
95-98 \\
\%\end{array}$ \\
\hline Aantal personen (x 1.000) & 10,6 & 10,7 & 11,1 & 11,4 & 7,4 \\
Percentage vrouwen & 99,0 & 99,0 & 99,1 & 99,1 & 0,1 \\
Lengte werkweek (uren) & 28,6 & 28,5 & 27,7 & 27,8 & $-2,8$ \\
Part-time werk (\%) & 51,8 & 52,6 & 52,7 & 52,3 & 8,1 \\
Gemiddelde leeftijd (jaren) & 32,8 & 33,2 & 33,3 & 33,6 & \\
\hline
\end{tabular}

Bron: SPMAROA

Uit de cijfers in tabel 2.1 blijkt dat het totaal aantal apothekersassistenten de afgelopen drie jaar is toegenomen van 10.600 in 1995 tot 11.400 in 1998; een jaarlijkse toename van circa $2,5 \%$. Het beroep van apothekersassistent is een typisch vrouwenberoep: slechts een op de honderd werknemers is een man. Tegenover de toename van het aantal apothekersassistenten staat een afname van het aantal uren dat de apothekersassistenten gemiddeld per week werken, van 28,6 uur per week in 1995 tot 27,8 uur per week in 1998. Dit is gepaard gegaan met een toename van het aantal mensen dat in deeltijd werkt. Deze ontwikkelingen samen hebben tot gevolg gehad dat het totale aantal uren dat wordt gewerkt is toegenomen. Vanwege de verkorting van de voltijds werkweek en de toename van de deeltijdarbeid is de toename van het aantal gewerkte uren echter niet zo groot als de groei van het aantal apothekersassistenten.

De gemiddelde leeftijd van de werkende apothekersassistenten is relatief laag, ongeveer 34 jaar. De afgelopen jaren is de gemiddelde leeftijd echter iets toegenomen. Deze toename is vergelijkbaar met die in andere beroepen waarin veel vrouwen werkzaam zijn. Zo is bijvoorbeeld de gemiddelde leeftijd van verpleegkundigen tussen 1995 en 1996 toegenomen van 34,7 naar 35,1 jaar (Van der Windt e.a., 1998). De oorzaak van deze toename moet gezocht worden in een veranderend arbeidsaanbodgedrag van vrouwen. Het huwelijk of het krijgen van kinderen vormen steeds minder een reden om te stoppen met werken (zie o.a. Vlasblom, 1998). Wel moet deze veranderende houding ten opzichte van een betaalde baan ondersteund worden met regelingen die de combinatie van werk en kinderen mogelijk maken. Ook voor apothekersassistenten zijn dergelijke maatregelen genomen, b.v. in de vorm van de regeling kinderopvang ${ }^{3}$. Het is daarom te verwachten dat ook in deze beroepsgroep in ieder geval een deel van de vrouwen steeds langer zal blijven werken. Dit betekent ook dat er de komende jaren

3. Deze regeling houdt in dat er kinderopvangplaatsen beschikbaar komen voor medewerkers die onder de CAO voor de apotheken vallen. De kosten voor deze plaatsen worden gedeeld door de apotheek, de werknemer (inkomensafhankelijke bijdrage) en de SBA, die het restant van de kosten dekt (Zie SBA, 1997). 
veranderingen te verwachten zijn in de vraag naar nieuw personeel: als men langer blijft werken, zal er een afnemende uitstroom van personeel te verwachten zijn.

Figuur 2.1 geeft een overzicht van de leeftijdsopboun van de op 1 januari 1998 werkende apothekersassistenten. Ook uit deze figuur blijkt dat de meeste apothekersassistenten jong zijn. Van de apothekersassistenten is $43 \%$ jonger dan 30 jaar. Het percentage oudere arbeidskrachten is daarentegen slechts $9 \%$. In 1995 waren deze beide percentages respectievelijk 45 en $7 \%$. De piek in de leeftijdsverdeling ligt tussen de 25 en de 30 jaar. Het lijkt er op dat men, na een aantal jaren in de apotheek werkzaam te zijn geweest ofwel stopt met werken ofwel een baan buiten de apotheek zoekt. Gezien het feit dat er vrijwel alleen vrouwen als apothekersassistent werkzaam zijn, ligt de conclusie voor de hand dat men zo rond die leeftijd stopt met werken omdat men de voorkeur geeft aan het verzorgen van de eigen kinderen. Als echter de trend dat men langer blijft werken doorzet, zal de piek in de leeftijdsverdeling de komende jaren bij steeds hogere leeftijden komen te liggen.

Figuur 2.1

Leeftijdsopbouw werkzame apothekersassistenten op 1-1-1998

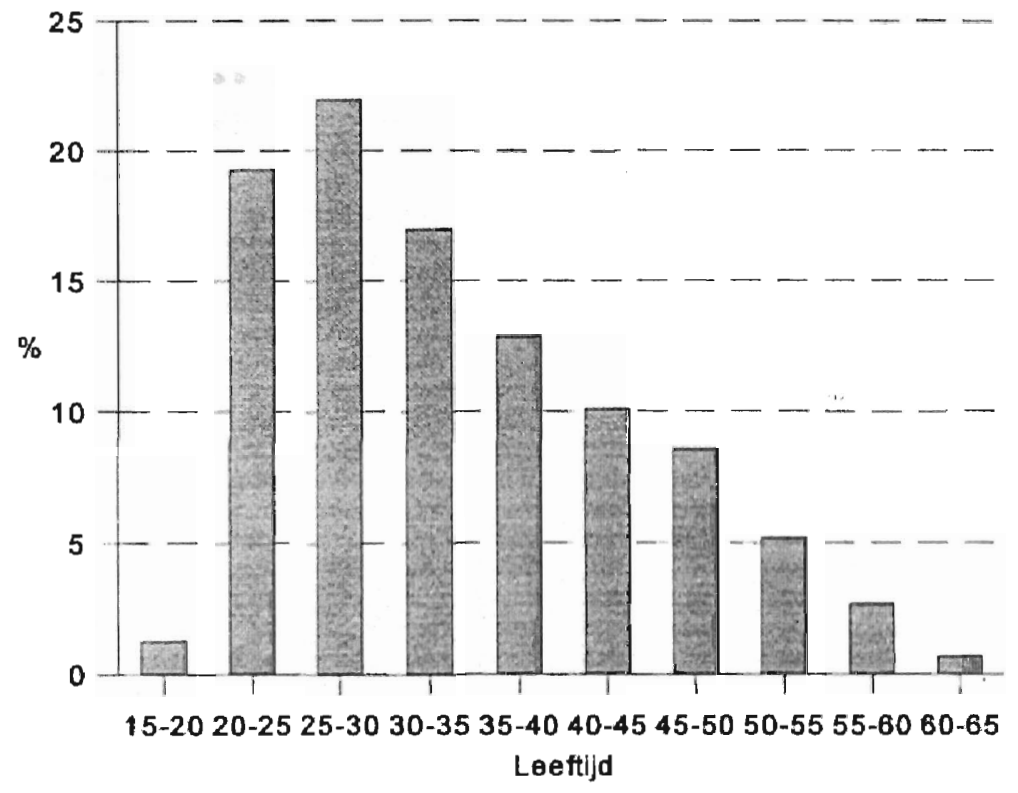

Bron: SPMA/ROA

Figuur 2.2 geeft een beeld van de lengte van het dienstverband van de op 1 januari 1998 werkzame apothekersassistenten. Voor een deel hangt de lengte van het dienstverband samen met de leeftijd: jonge werknemers kunnen nog geen lang dienstverband hebben. Toch zijn er een paar duidelijke pieken te zien in de figuur: ongeveer $12 \%$ van 
het personeel werkt nog geen jaar in de apotheek. Ook valt het op dat het aantal assistenten dat een dienstverband heeft van twee tot drie jaar relatief laag is. Blijkbaar is er in 1995 een relatief geringe instroom van assistenten geweest. De gemiddelde lengte van de nu bestaande dienstverbanden ligt rond de drie jaar, en slechts een minderheid van het personeel, namelijk $22 \%$, heeft een dienstverband dat al langer duurt dan tien jaar. Blijkbaar is het beroep van apothekersassistent geen beroep dat voor langere tijd op dezelfde plaats uitgeoefend wordt. Hierbij moet wel bedacht worden dat er hier sprake is van zogenaamde onvoltooide duren. Dat wil zeggen: het gaat hier om de lengte van dienstverbanden die nog niet afgelopen zijn. Als er relatief veel korte dienstverbanden zijn, zullen deze in figuur 2.2 alleen maar meetellen als ze op 1 januari bestaan. Dienstverbanden die na januari beginnen of voor eind december beëindigd waren, komen niet in de figuur voor. Dit leidt dus tot een overschatting van de gemiddełde lengte van een dienstverband. Aan de andere kant, de dienstverbanden die wel op 1 jaruari bestaan, lopen doorgaans nog langer door. De periode waarover ze doorlopen is in figuur 2.2 niet venwerkt. Dit laatste leidt dus tot een onderschatting van de gemiddelde lengte van een dienstvertand. Het is op theoretische gronden niet te zeggen welke van deze twee vertekeningen het sterkste effect zal hebben.

Figuur 2.2

Lengte dienstverband in jaren, werkzame apothekersassistenten op 1-1-1998

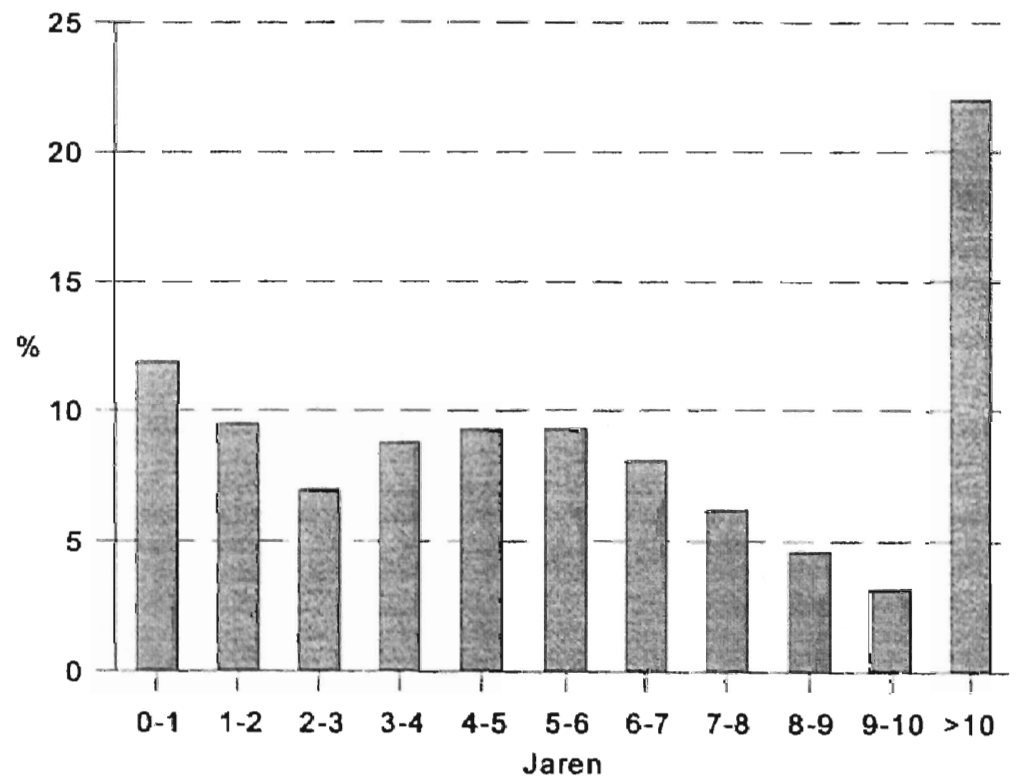

Bron: SPMAVROA 


\subsection{Niet-participerenden}

Naast de werkende apothekersassistenten onderscheiden we op de arbeidsmarkt voor apothekersassistenten de niet-participerenden. Dit zijn degenen die eerder als apothekersassistent gewerkt hebben en daarmee gestopt zijn, maar ook degenen die wel het benodigde diploma bezitten, maar nooit als apothekersassistent aan het werk gegaan zijn, en ook geen ander werk gevonden hebben. In tabel 2.2 staat aangegeven om welke aantallen mensen het hier gaat. De cijfers in deze tabel zijn gebaseerd op gegevens van het CBS en de SBA.

Tabel 2.2

Niet-participerende gediplomeerde apothekersassistenten, 1997

$\begin{array}{lr}\text { Aantal niet-participerenden } & 9.700 \\ \text { waarvan geregistreerd werkloos } & 900 \\ \text { waarvan niet direct beschikbaar } & 6.000 \\ & \\ \text { Leeftijdsverdeling } & 41 \% \\ \text { jonger dan } 40 \text { jaar } & 59 \% \\ \text { ouder dan } 40 \text { jaar } & \end{array}$

Bron: CBS/SBA

Uit de Enquête Beroepsbevolking (EBB) van het CBS kan worden afgeleid hoeveel mensen de opleiding tot apothekersassistent gevolgd hebben, maar op dit moment niet in dit beroep werkzaam zijn. Er zijn in 1997 ruim 26.000 mensen jonger dan 65 jaar die ooit de opleiding tot apothekersassistent afgerond hebben. Van hen hebben er in 1997 17.000 een betaalde baan. Van hen is $74 \%$ werkzaam als apothekersassistent of medisch laborant. Uit de in tabel 2.1 gepresenteerde gegevens van de SBA blijkt dat er 11.000 werkzaam zijn als apothekersassistent in de openbare apotheek. Dit betekent dat er een grote groep is, namelijk ruim $30 \%$ van het totaal aantal werkenden, die wel een baan heeft maar niet als apothekersassistent in de openbare apotheek. Deze laatste groep is zo verspreid over de verschillende beroepen dat er niet duidelijk beroepen zijn aan te wijzen waarin deze gediplomeerden werkzaam zijn. Een belangrijke groep wordt waarschijnlijk gevormd door de apothekersassistenten die werkzaam zijn in de ziekenhuisapotheken en de industrie. Om na te gaan in hoeverre een eventueel tekort aan apothekersassistenten opgevuld zou kunnen worden door het werven van mensen die werkzaam zijn in een ander beroep, is er eerst een nadere analyse nodig van de functies waarin deze mensen werkzaam zijn, en waarom ze een ander beroep gekozen hebben.

In 1997 zijn er ongeveer 9.700 gediplomeerden, die ooit de opleiding afgerond hebben maar op dit moment niet (meer) werkzaam zijn. In tabel 2.2 staat een aantal kengetallen over deze groep. Uit de gegevens van de SBA blijkt dat er van deze 9.700 zo'n 900 mensen als werkloos geregistreerd staan. De overigen zijn dus weliswaar gediplomeerd, maar bieden zich niet aan op de arbeidsmarkt. Gezien de omvang van de totale 
groep werkenden, is dit een enorme 'stille reserve', die in geval van oplopende tekorten van groot belang zou kunnen zijn om deze tekorten het hoofd te bieden. Het is dus van belang om te weten welke mensen er deel uit maken van deze 'stille arbeidsreserve', wat hun leeftijd is, en wat hun 'afstand tot de arbeidsmarkt' is. Opvallend hierbij is dat van de groep niet-participerenden volgens de EBB ongeveer 6.000 mensen niet beschikbaar is voor de arbeidsmarkt; dat wil zeggen tweederde van de 'stille arbeidsreserve'. Dit geeft weer aan dat er blijkbaar voor de apothekersassistenten zwaarwegende argumenten zijn om na verloop van tijd te stoppen met werken en niet terug te keren op de arbeidsmarkt. Ruim de helft van de stille reserve is ook ouder dan 40 jaar. Aangenomen mag worden dat het hier voor een groot deel gaat om vrouwen die ooit gestopt zijn met werken vanwege de verzorging van hun (eigen) kinderen. Als deze groep weer ingezet moet worden op de arbeidsmarkt, zal er een duidelijke beleidsinspanning nodig zijn. Er zijn overigens inmiddels stappen in die richting gezet, zoals bijvoorbeeld de reeds genoemde regeling kinderopvang.

\subsection{Instroom van gediplomeerde apothekersassistenten}

De instroom van nieuwe werknemers vindt plaats uit twee bronnen. De eerste bron die we onderscheiden zijn de schoolverlaters, de tweede bron is de instroom uit andere beroepen en niet-participerenden. Voordat we de instroom uit deze bronnen afzonderlijk zullen bespreken, geven we eerst een overzicht van de totale instroom en een indicatie welk deel van de instroom gevormd wordt door schoolverlaters en welk deel afkomstig is uit andere beroepen en de groep niet-participerenden. De informatie uit de bestanden van de SPMA is niet voldoende om te bepalen wat de herkomst is van de instromers: er kan alleen nagegaan worden of iemand al eerder een baan bij een apotheek heeft gehad. De overige instroom moet dus (per definitie) bestaan uit schoolverlaters en anderen die de laatste jaren niet in een apotheek werkzaam zijn geweest. Op basis van een tweetal aannamen maken we een opsplitsing tussen deze twee groepen. De eerste aanname betreft de vraag wanneer er van doorstroom gesproken wordt. Als er tussen twee betrekkingen een korte periode van werkloosheid optreedt, moet bepaald worden hoe lang deze maximaal mag duren om van doorstroom te spreken. Hier is gekozen voor 12 maanden. De tweede aanname betreft de manier waarop bepaald wordt wat een schoolverlater is. Er is voor gekozen om de instroom die jonger is dan 25 jaar, en die niet eerder een baan als apothekersassistent heeft gehad als schoolverlater te beschouwen.

\section{Totale instroom}

Voordat we een gedetailleerde beschrijving gaan geven van de instroom van gediplomeerde apothekersassistenten in de openbare apotheek, geven we eerst een overzicht van de omvang van deze instroom. In tabel 2.3 staat aangegeven hoe groot de instroom de afgelopen jaren is geweest, en hoe zij verdeeld was over de verschillende bronnen. De totale instroom bedroeg ongeveer 1.300 assistenten per jaar. In 1995 lag 
de instroom met een omvang van ongeveer 1.000 werknemers beduidend lager. De schoolverlaters vormen in totaal $46 \%$ van de instroom. Van de totale instroom is ongeveer $40 \%$ afkomstig uit een andere apotheek. Het blijkt dat slechts een relatief klein deel van de instromers herintreder is of instroomt vanuit een andere beroepsgroep, namelijk $14 \%$ van de totale instroom. Vanwege de doorstroom (de baan-baan mobiliteit binnen de sector, hier aangegeven met de 'instroom uit andere apotheek') is de totale instroom groter dan de werkgelegenheidsgroei. $\mathrm{Er}$ is sprake van een zogenaamde vacatureketen die alleen betrekking heeft op de doorstroom van werkenden van de ene apotheek naar de andere. Als de vacatures die door deze mensen vervuld worden, worden meegeteld bij de totale vraag zal er dus een aanzienlijke overschatting van de vraag naar nieuwkomers plaatsvinden.

\section{Tabel 2.3}

Instroom opgesplitst naar herkomst, 1995 - 1997

\begin{tabular}{lrrr}
\hline & 1995 & 1996 & 1997 \\
\hline Totale instroom & 1.030 & 1.320 & 1.300 \\
Instroom uit andere apotheek & 420 & 470 & 560 \\
Geschatte instroom van schoolverlaters $^{\text {a) }}$ & 460 & 680 & 550 \\
Geschatte instroom van andere bronnen $^{\text {b) }}$ & 160 & 180 & 140 \\
\end{tabular}

a) Instroom jonger dan 25 jaar voor zover niet afkomstig uit een andere apotheek.

b) Dit omvat o.a. herintreders, werklozen, elders werkzamen.

Bron: SPMAVROA

Tabel 2.4

Procentuele verdeling van de instroom van apothekersassistenten over de maanden van het jaar, gemiddelde 1995 - 1997

\begin{tabular}{lcccc}
\hline & $\%$ van het total & \multicolumn{3}{c}{$\begin{array}{c}\text { Componenten van de instroom } \\
\text { uit andere } \\
\text { apotheek } \\
\text { schoolverlaters }\end{array}$} \\
& & $\%$ & $\%$ & $\%$ \\
\hline Januari & 1,5 & 34 & 32 & 34 \\
Februari & 4,8 & 32 & 41 & 27 \\
Maart & 4,5 & 26 & 53 & 20 \\
April & 7,9 & 22 & 64 & 15 \\
Mei & 6,1 & 44 & 40 & 16 \\
Juni & 14,3 & 73 & 17 & 10 \\
Juli & 19,0 & 74 & 18 & 13 \\
Augustus & 7,3 & 49 & 37 & 16 \\
September & 9,3 & 38 & 46 & 20 \\
Oktober & 10,9 & 27 & 63 & 16 \\
November & 7,7 & 32 & 56 & 14 \\
December & 6,8 & 32 & 52 & \\
Totaal & 100,0 & 46 & 40 & \\
\hline
\end{tabular}

a) Gemeten als instromers die jonger zijn dan 25 jaar.

Bron: SPMAROA 
Vervolgens wordt in tabel 2.4 een indruk gegeven van de verdeling van de totale instroom van personeel per maand. Het blijkt dat de instroom niet gelijkelijk over het jaar is verdeeld. Duidelijk is te zien dat de instroom een piek kent rond de maanden juni en juli. Met name in deze maanden nemen jongeren (jonger dan vijfentwintig jaar) een relatief groot deel van de instroom voor hun rekening. Vanwege de leeftijd moeten dit schoolverlaters zijn. Er is dus blijkbaar zoveel vraag naar assistenten dat een groot deel van de schoolverlaters direct na het behalen van het diploma een baan kan vinden. Een tweede piek is te vinden in oktober, aansluitend aan de her-examens.

\section{Instroom van schoolverlaters}

Nadat in grote lijnen is geschetst welk deel van de jaarlijkse instroom betrekking heeft op schoolverlaters, zal in de volgende tabellen nadere informatie gegeven worden over het aantal schoolverlaters uit de (M)DGO-opleiding tot apothekersassistent en de beroepen en werkplekken waar deze schoolverlaters terechtkomen na het behalen van hun diploma.

In tabel 2.5 wordt een overzicht gegeven van de aantallen leerlingen die de opleiding tot apothekersassistent volgden. De gegevens over de leerlingen in schooljaar 1997 1998 zijn nog niet beschikbaar. Duidelijk is te zien dat er in het begin van de jaren '90 een toenemende belangstelling was voor de opleiding tot apothekersassistent: de aantallen leerlingen voor het eerste jaar namen toe tot 1.350 in 1993. Daarna is er sprake van sterk teruglopende leerling aantallen. Het aantal gediplomeerden is in 1994 het grootst. Blijkbaar is niet alieen de belangstelling 'aan de poort' afgenomen, maar is ook de tussentijdse uitval toegenomen. Wel is het aantal mensen dat in 1994 staatsexamen heeft afgelegd groter dan gemiddeld. Misschien dat een aantal uitvallers alsnog via het staatsexamen de opleiding heeft afgerond.

Tabel 2.5

Aantallen scholieren in opleiding tot apothekersassistent, 1991 - $1996^{\text {al }}$

\begin{tabular}{lrrrrrr}
\hline & 1991 & 1992 & 1993 & 1994 & 1995 & 1996 \\
\hline 1e leerjaar & 1.250 & 1.281 & 1.350 & 1.312 & 1.059 & 911 \\
2e leerjaar & 988 & 1.031 & 1.018 & 1.067 & 1.032 & 901 \\
3e leerjaar & 988 & 992 & 1.100 & 1.095 & 1.231 & 988 \\
Gediplomeerden: & & & & & & \\
(M)DGO & 734 & 723 & 720 & 836 & 773 & 853 \\
Staatsexamen & 62 & 65 & 63 & 134 & 112 & 68
\end{tabular}

\footnotetext{
a) Pas vanaf het eerste leerjaar in 1993 zijn de cijfers per leerjaar bekend voor apothekersassistenten afzonderlijk, daarvoor is een verdeelsleutel gebruikt. De gegevens per leerjaar zijn van het ROA, die over de aantallen gediplomeerden zijn van het SBA.

Bron: SBAVROA
}

Lang niet alle leerlingen die de opleiding tot apothekersassistent hebben gevolgd zullen ook een beroep in die richting kiezen. In tabel 2.6 staat aangegeven wat enige 
tijd na afstuderen de belangrijkste bezigheid van de schoolverlaters is. Een gedeelte blijkt na het (succesvol) afronden van de opleiding een volgende opleiding te zijn gaan volgen. Het merendeel gaat echter de arbeidsmarkt op. Ook hier lijkt 1994 een afwijkend jaar te zijn. Van de mensen die in dat jaar zijn afgestudeerd volgt een relatief groot deel nog een andere opleiding. Ook zijn er dat jaar relatief veel schoolverlaters werkloos. Dit komt overeen met de bevinding uit figuur 2.2 dat het aantal mensen dat in 1995 een baan als apothekersassistent begonnen is lager ligt dan het gemiddelde.

Tabel 2.6

Belangrijkste activiteit van gedipjomeerde apothekersassistenten, $1991-1996^{\text {s) }}$

\begin{tabular}{lrrrrrr} 
& $\begin{array}{r}1991 \\
\%\end{array}$ & $\begin{array}{r}1992 \\
\%\end{array}$ & $\begin{array}{r}1993 \\
\%\end{array}$ & $\begin{array}{r}1994 \\
\%\end{array}$ & $\begin{array}{r}1995 \\
\%\end{array}$ & $\begin{array}{r}1996 \\
\%\end{array}$ \\
\hline Scholier & 5 & 7 & 7 & 10 & 6 & 9 \\
Werkzaam & 94 & 92 & 90 & 83 & 87 & 86 \\
LLW/in-service & - & 1 & 0 & 1 & 1 & 1 \\
Werkloos & 1 & 0 & 3 & 6 & 5 & 2 \\
Anders & 0 & 0 & 0 & 1 & 1 & 2
\end{tabular}

a) Dit is de activiteit op enquêtemoment: voor de enquêtes tot 1995 is dat mei, voor de enquêtes vanaf 1996 is dat oktober van het jaar na afstuderen.

Bron: ROA (RUBS)

Van de werkenden met een opleiding tot apothekersassistent kunnen we nagaan in welk beroep zij werkzaam zijn. In tabel 2.7 staat aangegeven in welke mate men daadwerkelijk in het beroep van apothekersassistent terecht komt. De tabel laat zien dat het merendeel van de schoolverlaters met de opleiding tot apothekersassistent ook daadwerkelijk apothekersassistent wordt, maar zeker de laatste jaren is er een grotere groep die buiten de gezondheidszorg werkzaam is. Niet duidelijk is of dat veroorzaakt wordt door het feit dat er geen baan beschikbaar is of omdat andere banen de voorkeur genieten.

Tabel 2.7

Beroepen van werkzame gediplomeerde apothekersassistenten, 1991 - 1996

\begin{tabular}{lrrrrrr}
\hline & $\begin{array}{r}1991 \\
\%\end{array}$ & $\begin{array}{r}1992 \\
\%\end{array}$ & $\begin{array}{r}1993 \\
\%\end{array}$ & $\begin{array}{r}1994 \\
\%\end{array}$ & $\begin{array}{r}1995 \\
\%\end{array}$ & $\begin{array}{r}1996 \\
\%\end{array}$ \\
\hline Apothekersassistent & 91 & 82 & 81 & 84 & 79 & 88 \\
Overig gezondheidszorg & 7 & 14 & 15 & 13 & 5 & 5 \\
Buiten gezondheidszorg & 2 & 4 & 4 & 3 & 16 & 7 \\
\hline
\end{tabular}

Bron: ROA (RUBS)

Als laatste kan nagegaan worden in welke mate de apothekersassistenten een baan vinden in de openbare apotheek. Tabel 2.8 geeft een overzicht van de verschillende sectoren waar de apothekersassistenten werkzaam zijn. Alhoewel het merendeel werk- 
zaam is in de openbare apotheek, is er zeker in 1994 en 1995 te zien dat een relatief groot deel als apothekersassistent werkzaam is buiten de openbare apotheek.

Tabel 2.8

Werkplekken van gediplomeerde apothekersassistenten, 1991 - 1996

\begin{tabular}{|c|c|c|c|c|c|c|}
\hline & $\begin{array}{r}1991 \\
\%\end{array}$ & $\begin{array}{r}1992 \\
\%\end{array}$ & $\begin{array}{r}1993 \\
\%\end{array}$ & $\begin{array}{r}1994 \\
\%\end{array}$ & $\begin{array}{r}1995 \\
\%\end{array}$ & $\begin{array}{r}1996 \\
\%\end{array}$ \\
\hline $\begin{array}{l}\text { Apotheken } \\
\text { Ziekenhuizen } \\
\text { Praktijken en centra } \\
\text { Tehuizen } \\
\text { Overige }\end{array}$ & $\begin{array}{r}91 \\
7 \\
1 \\
0 \\
1\end{array}$ & $\begin{array}{r}96 \\
3 \\
1 \\
0 \\
0\end{array}$ & $\begin{array}{r}95 \\
4 \\
1 \\
0 \\
0\end{array}$ & $\begin{array}{r}88 \\
7 \\
4 \\
0 \\
1\end{array}$ & $\begin{array}{r}82 \\
8 \\
2 \\
7 \\
0\end{array}$ & $\begin{array}{r}95 \\
3 \\
1 \\
0 \\
1\end{array}$ \\
\hline
\end{tabular}

Bron: ROA (RUBS)

Als de informatie uit de tabellen samengenomen wordt, blijkt dat er vanuit het oogpunt van de openbare apotheken een vrij grote 'lekkage' optreedt bij de arbeidsmarktinstroom van de schoolverlaters van de opleiding tot apothekersassistent. Als voorbeeld noemen we 1996. In dit jaar gaat $86 \%$ van de gediplomeerde schoolverlaters werken, waarvan $88 \%$ als apothekersassistent, waarvan $95 \%$ in een openbare apotheek. Dit betekent dat in dat jaar slechts $72 \%(0,86 \times 0,88 \times 0,95=0,72)$ van degenen die het diploma haalden van de opleiding tot apothekersassistent in de openbare apotheek terecht komt.

Tabel 2.9

Opleidingsachtergrond van (werkzame) apothekersassistenten, 1991 - 1996

\begin{tabular}{lrrrrrr}
\hline & $\begin{array}{r}1991 \\
\%\end{array}$ & $\begin{array}{r}1992 \\
\%\end{array}$ & $\begin{array}{r}1993 \\
\%\end{array}$ & $\begin{array}{r}1994 \\
\%\end{array}$ & $\begin{array}{r}1995 \\
\%\end{array}$ & $\begin{array}{r}1996 \\
\%\end{array}$ \\
\hline MBO Ap.ass. & 91 & 88 & 82 & 80 & 72 & 70 \\
MBO assist. gezondh. & 4 & 9 & 18 & 13 & 24 & 21 \\
MBO overig & 1 & 0 & 0 & 0 & 1 & 2 \\
Overig & 5 & 3 & 0 & 7 & 2 & 7 \\
Total & 100 & 100 & 100 & 100 & 100 & 100 \\
\hline
\end{tabular}

Bron: ROA (RUBS)

Behalve de informatie over het beroep en de werkplek van de afgestudeerde apothekersassistenten, kunnen we ook nagaan wat de opleidingsachtergrond is van diegenen die als apothekersassistent werkzaam zijn. Tabel 2.9 geeft een overzicht van de opleidingsachtergrond van de schoolverlaters die anderhalf jaar na afstuderen als apothekersassistent werkzaam zijn. Hierbij is geen onderscheid gemaakt naar de werkplek die de apothekersassistenten hebben, met andere woorden, ook apothekersassistenten die in ziekenhuizen en dokterspraktijken werkzaam zijn, zijn in deze tabel meegenomen. De tabel geeft een onverwacht beeld. De cijfers geven aan dat er blijk- 
baar in toenemende mate sprake is van werving van personeel buiten de eigenlijke opleiding om: een steeds groter deel komt uit andere opleidingen dan de opleiding tot apothekersassistent. Weliswaar komt een groeiend deel uit zeer nauw verwante opleidingen, maar toch lijkt het beroep in toenemende mate toegankelijk te zijn voor mensen met een andere opleidingsachtergrond. Dit is een opmerkelijke bevinding, omdat de toegang tot het beroep van apothekersassistent in principe voorbehouden is aan mensen met de opleiding tot apothekersassistent. Dat in de praktijk ook mensen met een andere opleiding dit beroep uitoefenen kan meerdere oorzaken hebben. Het kan zijn dat er een tekort aan apothekersassistenten is ontstaan dat opgevuld wordt door mensen met een verwante opleiding aan te nemen. Gezien de relatief hoge werkloosheid in deze periode onder gediplomeerde apothekersassistenten (zoals aangegeven in tabel 2.2) is dit echter niet aannemelijk. Ook kan het zijn dat de vaardigheden die vereist worden niet altijd zo specifiek zijn dat men die uitsluitend verwerft in de opleiding tot apothekersassistent. Nader - en gedetailleerder - onderzoek zou aan moeten tonen of deze resultaten toe zijn te schrijven aan onnauwkeurigheden in de data (b.v. codeerfouten bij opleiding of beroep), of dat sommige apothekers zich door de tekorten gedwongen zien personeel aan te nemen dat formeel gesproken niet aangenomen had mogen worden. Beide bevindingen, het relatief grote aantal afgestudeerden dat buiten de apotheek werk vindt, en het aantal in de apotheek werkzamen met een andere opleidingsachtergrond, kunnen er op duiden dat de afgrenzingen van de arbeidsmarkt voor apothekersassistenten toch minder strikt zijn dan voor een geprofessionaliseerde vakdeelmarkt verwacht mag worden.

\section{Instroom van niet-schoolverlaters}

In tabel 2.1 werd al aangegeven hoe de verdeling van de instroom over de diverse bronnen is. Uit deze tabel blijkt dat er ieder jaar ongeveer 150 a 200 mensen instromen die geen schoolverlater zijn of daarvoor een baan hadden als apothekersassistent. Deze groep betreft enerzijds mensen die eerst elders een baan gehad hebben en daama alsnog besluiten om apothekersassistent te worden, en anderzijds herintreders op de arbeidsmarkt. Omdat op basis van de huidige gegevens niet kan worden nagegaan wat de herkomst van deze 'overige instroom' is, is het niet mogelijk om er meer inhoudelijke uitspraken over te doen. Nader onderzoek, bijvoorbeeld op basis van een uitgebreide enquête in de apotheken, zou meer informatie op moeten leveren.

Het bestaan van deze instroom uit andere bronnen is niet in tegenspraak met het hierboven gesignaleerde feit, dat ondanks de groei van de werkgelegenheid in de apotheken, een steeds groter deel van de schoolvertaters niet in de apotheek terecht komt. Dit lijkt er op te duiden dat voor de werving van personeel de schoolverlaters van afnemende betekenis zijn, en dat in toenemende mate herintreders worden aangetrokken. Dit proces van een kleiner wordende arbeidsmarktinstroom van schoolverlaters en een relatief grote instroom vanuit de overige groepen kan in principe twee oorzaken hebben. Enerzijds kunnen schoolverlaters met de opleiding tot apothekersassistent betere 
mogelijkheden hebben buiten de apotheek, waardoor de apotheken gectwongen zijn meer ouderen in dienst te nemen. Anderzijds is het mogelijk dat er een steeds groter aanbod komt van oudere herintreders en dat apothekers aan hen de voorkeur geven boven de schoolverlaters, zodat schoolverlaters gedwongen worden om elders te gaan werken. Ook hier zou nader onderzoek nodig zijn om meer duidelijkheid te krijgen op dit punt.

\subsection{Uitstroom van werkenden}

Tegenover de arbeidsmarktinstroom van schoolverlaters en herintreders staat de uitstroom van de werkenden uit de apotheken. Deze uitstroom vindt plaats naar vier mogelijke bestemmingen. Er is uitstroom mogelijk naar een andere apotheek, naar een baan buiten de apotheek, naar non-participatie en tenslotte naar VUT en pensioen. Op basis van de nu beschikbare cijfers is deze onderverdeling echter niet te maken. Wel is het mogelijk om de totale uitstroom te bepalen. Ook is na te gaan welk deel van deze uitstroom vervolgens een baan in een andere apotheek krijgt. De verdeling van de overige uitstroom is niet mogelijk. Op basis van een (enigszins arbitrair) leeftijdscriterium kan in principe een inschatting gemaakt worden van de uitstroom naar VUT of pensioen, maar het onderscheid tussen uitstroom naar een baan buiten de apotheek of naar non-participatie kan niet gemaakt worden. Tabel 2.10 geeft een overzicht van de omvang van de uitstroom per jaar, en de verdeling over de te onderscheiden bestemmingen. Vanwege de werkgelegenheidsgroei is de totale uitstroom lager dan de instroom. Ongeveer de helft van de uitstroom vindt aansluitend een nieuwe baan in de openbare apotheek ${ }^{4}$. De andere helft, ongeveer 500 per jaar, gaat in ieder geval op de korte termijn als werknemer voor de openbare apotheek verloren.

Tabel 2.10

Uitstroom opgesplitst naar bestemming, 1995 - 1997

\begin{tabular}{lrrr}
\hline & 1995 & 1996 & 1997 \\
\hline Totale uitstroom & 880 & 890 & 1.030 \\
Uitstroom naar andere apotheek & 380 & 390 & 490 \\
Geschatte uitstroom naar VUT/pensioen ${ }^{\text {a) }}$ & 50 & 50 & 40 \\
Geschatte ultstroom naar andere bestemmingen $^{\text {b) }}$ & 450 & 450 & 500 \\
\hline
\end{tabular}

a) Uitstroom ouder dan 60 jaar voor zover niet vertrokken naar een andere apotheek.

b) Dit omvat o.a. non-participanten, werklozen en elders werkzamen.

Bron: SPMAROA

Tabel 2.11 geeft een overzicht van de uitstroom per maand en de verdeling daarvan over de twee onderscheiden bestemmingen: een baan bij een andere apotheek of uit-

4. Vanwege betrekkingen die korter duren dan een jaar komen de uitstroom "naar andere apotheek', zoals vermeld in tabel 2.10 en de instroom 'uit andere apotheek' zoals vermeld in tabel 2.3 niet exact overeen. 
stroom uit de sector. Dat wil zeggen ofwel uitstroom van de arbeidsmarkt of uitstroom naar een baan buiten de sector. De data staan helaas niet toe onderscheid te maken tussen deze laatste twee categorieën. Alleen de uitstroom van VUTers en gepensioneerden is te onderscheiden, maar deze uitstroom is zo klein dat het onderscheiden van deze afzonderlijke groepen voor deze tabel niet de moeite loont. In tegenstelling tot de instroom kent de uitstroom vrijwel geen seizoenspatroon. Uit de uitstroomcijfers blijkt dat ongeveer de helft van de uitstroom binnen een jaar weer een baan heeft als apothekersassistent. Deze uitstroom vormt dus voor de afzonderlijke apotheken mogelijk wel een probleem, maar voor de sector als geheol niet: de werknemers blijven immers voor de sector behouden. De uitstroom naar elders vormt op sectorniveau wel een probleem: deze arbeidskrachten gaan 'verioren' en moeten, tenzij er een krimpende werkgelegenheid is, worden vervangen door nieuwe arbeidskrachten.

Niet alleen kennis over de omvang van de uitstroom is belangrijk. Het is ook van belang om te weten in hoeverre de uitstroom samenhangt met kenmerken van de betrokken werknemers. Dit verschil in gedrag, samen met het in de figuren 2.1 en 2.2 gegeven overzicht van de opbouw van het personeelsbestand van de openbare apotheken naar leeftijd en lengte van dienstverband, geeft een indicatie voor de verwachte uitstroom van personeel in de toekomst. In de volgende tabellen zal aangegeven worden in hoeverre er verschillen bestaan tussen de mobiliteit van de apothekersassistenten naar leeftijd en lengte van het dienstverband. Hierbij zal expliciet onderscheid gemaakt worden tussen de baan-baan mobiliteit binnen de sector en uitstroom uit de sector.

Tabel 2.11

Procentuele verdeling van de arbeidsmarktuitstroom van apothekersassistenten over de maanden van het jaar, gemiddelde 1995 - 1997

\begin{tabular}{lrcc}
\hline \% van het totaal & \multicolumn{2}{c}{$\begin{array}{c}\text { Componenten van de uitstroom } \\
\text { naar andere apotheek } \\
\%\end{array}$} & $\begin{array}{c}\% \\
\%\end{array}$ \\
\hline Januari & & & 58 \\
Februari & 4,1 & 41 & 51 \\
Maart & 8,1 & 49 & 53 \\
April & 9,3 & 46 & 38 \\
Mei & 12,3 & 62 & 57 \\
Juni & 7,9 & 44 & 58 \\
Juli & 8,7 & 41 & 63 \\
Augustus & 10,4 & 42 & 59 \\
September & 8,2 & 37 & 40 \\
Oktober & 8,7 & 41 & 63 \\
November & 10,9 & 60 & 69 \\
December & 6,4 & 47 & 53 \\
& 5,0 & 31 & \\
Totaal & 100,0 & 47 & \\
\hline
\end{tabular}

Bron: SPMAVROA 
Tabel 2.12

Uitstrcompercentages werkzame apothekersassistenten naar leeftijd, gemiddelde 1995 - 1997

\begin{tabular}{lccc}
\hline Leeftjd & $\begin{array}{c}\text { Andere baan als } \\
\text { apothekersassistent } \\
\%\end{array}$ & $\begin{array}{c}\text { Uitstroom } \\
\text { uit de sector } \\
\%\end{array}$ & $\begin{array}{c}\text { Totaal } \\
\%\end{array}$ \\
\hline jonger dan 20 jaar & 14,0 & 3,6 & 17,6 \\
$20-25$ jaar & 7,4 & 5,1 & 12,5 \\
$25-30$ jaar & 4,1 & 5,7 & 9,8 \\
$30-35$ jaar & 2,3 & 5,2 & 7,5 \\
$35-40$ jaar & 2,1 & 3,1 & 5,2 \\
$40-45$ jaar & 2,2 & 2,2 & 4,4 \\
$45-50$ jaar & 1,8 & 2,6 & 4,4 \\
$50-55$ jaar & 1,5 & 3,0 & 4,5 \\
ouder dan 55 jaar & 0,6 & 10,5 & 11,1 \\
Totaal & 3,8 & 4,3 & 8,1 \\
\hline
\end{tabular}

Bron: SBAVROA

In tabel 2.12 staat per leeftjidscategorie aangegeven wat de kans is dat mensen die op 1 januari van het jaar in dienst zijn, in de loop van het jaar hun betrekking verlaten. Het blijkt dat er een duidelijk verband is tussen de uitstroom en de leeftijd. Vooral jongeren kennen een hoog uitstroompercentage. Hoe ouder men wordt, des te groter wordt de kans dat men blijft werken in de baan die men heeft. Opvallend is dat baan-baan mobiliteit binnen de sector vooral voorkomt bij jongeren. Zodra men ouder is dan 25 , betekent het verlaten van een baan in veel gevalien ook dat men de sector verlaat.

Tabel 2.13

Uitstroompercentages werkzame apothekersassistenten naar lengte dienstverband, gemiddelde 1995 - 1997

\begin{tabular}{lccc}
\hline Lengte dienstverband & $\begin{array}{c}\text { Andere baan als } \\
\text { apothekersassistent } \\
\%\end{array}$ & $\begin{array}{c}\text { Uitstroom } \\
\text { uit de sector } \\
\%\end{array}$ & $\begin{array}{c}\text { Totaal } \\
\%\end{array}$ \\
\hline 0-3 maanden & 13,8 & 13,0 & 26,8 \\
3-6 maanden & 11,9 & 8,2 & 20,1 \\
6-9 maanden & 7,9 & 6,2 & 14,1 \\
$9-12$ maanden & 7,8 & 8,2 & 16,0 \\
1-2 jaar & 4,6 & 5,1 & 9,7 \\
2-3 jaar & 4,2 & 4,4 & 8,6 \\
langer dan 3 jaar & 2,2 & 3,2 & 5,4 \\
Totaal & 3,8 & 4,3 & 8,1 \\
\hline
\end{tabular}

Bron: SPMA/ROA

In tabel 2.13 wordt het uitstroompercentage van werkenden gedurende het jaar gerelateerd aan de tijd dat ze reeds in dienst zijn. Het blijkt dat vooral werkenden die een kortere periode in dienst zijn een relatief hoge kans op uitstroom hebben, terwijl diegenen die reeds langer in dienst zijn een lagere kans hebben op het beëindigen van 
hun dienstverband. Dit hangt waarschijnlijk ten dele samen met de hoge uitstroompercentages van jongeren. Jongeren hebben namelijk gemiddeld genomen een korter dienstverband. Er is, naar lengte van het dienstverband gemeten, bijna geen verschil in uitstroombestemming. De hoge uitstroomkans voor degenen die kortere tijd in dienst zijn suggereert dat de meeste dienstverbanden van korte duur zijn. Dit patroon is ten dele schijn: ter vergelijking staat in tabel 2.14 de lengte van de dienstverbanden bij afloop. Hieruit blijkt dat het merendeel van de dienstverbanden in totaal toch meer dan twee jaar geduurd heeft. Ongeveer $30 \%$ van de beëindigde betrekkingen heeft korter dan een jaar geduurd.

Tabel 2.14

Lengte dienstverband bij afloop dienstverband, gemiddelde 1995 - 1997

Lengte dienstverband

$\%$

0-3 maanden

9,4

3-6 maanden

8,6

6-9 maanden

6,2

9-12 maanden

1-2 jaar

6,9

2-3 jaar

15,9

langer dan 3 jaar

11,5

41,5

Bron: SPMAROA

Er is een aantal verschillen tussen tabel 2.13 en 2.14. Deze verschillen worden veroorzaakt door het in paragraaf 2.2 al genoemde probleem van de zogenaamde 'onvoltooide duren'. Tabel 2.13 geeft aan hoe groot de kans is dat het dienstverband eindigt, gegeven de lengte van een dienstverband tot nu toe, maar niet hoelang het nog gaat duren. Tabel 2.14 geeft aan hoe lang een dienstverband geduurd heeft, gegeven het feit dat het is afgelopen. $\mathrm{Er}$ is dus in beide tabellen een andere percenteerbasis gebruikt: in tabel 2.13 is dat het totaal aantal werkenden, in tabel 2.14 is dit het aantal beëindigde betrekkingen. Om een inschatting te maken van de verwachte mobiliteit in de sector is dus tabel 2.13 het uitgangspunt. Om na te gaan wat de verwachte lengte van een dienstverband zal zijn, is tabel 2.14 het uitgangspunt. 


\section{Toekomstige ontwikkelingen op de arbeidsmarkt}

\subsection{Inleiding}

Uit verschillende eerdere studies komt naar voren dat de tekorten aan mensen met een opleiding tot apothekersassistent vanaf 1997 zullen blijven stijgen. Doel van de hier gepresenteerde prognoses is om een duidelijker beeld te krijgen of deze problemen ook op zullen gaan treden bij het vinden van apothekersassistenten voor de openbare apotheek. De prognoseperiode die wordt gehanteerd loopt van 1998 tot 2007. Dit houdt in dat alle vraag- en aanbodprognoses gegeven worden vanaf 1998 tot en met 2006.

In paragraaf 3.2 wordt eerst stil gestaan bij de methodiek die voor het opstellen van de prognoses gehanteerd zal worden. Er worden prognoses gegeven voor zowel de vraag naar als het aanbod van gediplomeerde apothekersassistenten. Bij de vraag naar gediplomeerde apothekersassistenten wordt een onderscheid gemaakt tussen de uitbreidingsvraag (de werkgelegenheidsontwikkeling) en de vervangingsvraag. Dat is de vraag die ontstaat wanneer vertrekkende werknemers moeten worden vervangen door nieuwkomers. De uitbreidingsvraag en de vervangingsvraag vormen samen de totale vraag naar nieuwkomers op de arbeidsmarkt (baanopeningen). Tegenover deze totale vraag naar nieuwkomers staat het verwachte aanbod van nieuwkomers, bestaande uit de toekomstige instroom op de arbeidsmarkt van schoolverlaters van de opleiding tot apothekersassistent. In paragraaf 3.3 en 3.4 zullen de prognoses van de vraag- en aanbodontwikkelingen op de arbeidsmarkt voor apothekersassistenten worden gepresenteerd. In paragraaf 3.5 zal worden stilgestaan bij de te verwachten knelpunten op de arbeidsmarkt. Paragraaf 3.6 zal kort stilstaan bij de verschillen en overeenkomsten tussen de hier gepresenteerde arbeidsmarktprognoses voor apothekersassistenten en enkele eerder gemaakte prognoses.

\subsection{Stromen op de arbeidsmarkt}

Het ROA-rapport De arbeidsmarkt naar opleiding en beroep tot 2002 (ROA, 1997a) onderscheidt een drietal vraag- en aanbodcomponenten op de arbeidsmarkt: de uitbreidingsvraag, de vervangingsvraag en de instroom van schoolverlaters. De uitbreidingsvraag en vervangingsvraag samen bepalen het totaal aantal baanopeningen op de arbeidsmarkt. De uitbreidingsvraag is de vraag naar nieuwe arbeidskrachten die ontstaat door groei of krimp van de werkgelegenheid, dus de gewenste verandering in de omvang van het aantal werkenden. De vervangingsvraag is de vraag die ontstaat doordat door pensionering, arbeidsongeschiktheid of (tijdelijke) terugtrekking van de arbeidsmarkt opengevallen arbeidsplaatsen opnieuw moeten worden opgevuld. Het aantal baanopeningen is de som van de vervangingsvraag en de uitbreidingsvraag: hoeveel mensen zijn er nodig - als nieuwe instroom - om, gegeven de uitstroom van werkenden, de omvang van het personeelsbestand toch op de juiste omvang te houden. Deze aanpak gaat uit van de waargenomen netto stromen. Hierbij wordt baan- 
baan mobiliteit buiten beschouwing gelaten. De data van de SPMA geven echter een zeer gedetailleerd beeld van de bruto stromen die optreden. Een overzicht van deze stromen is in het vorige hoofdstuk gegeven. Met behulp van deze data kan in het hier gebruikte model de vraag naar en het aanbod van apothekersassistenten bepaald worden aan de hand van de stromen die op de arbeidsmarkt plaatsvinden. Er worden daartoe een drietal arbeidsmarktposities en de stromen daartussen onderscheiden. Allereerst zijn er de scholieren die nu in opleiding zijn tot apothekersassistent. Als tweede zijn er de werkende apothekersassistenten. Ten slotte worden de niet-werkenden onderscheiden, zoals werklozen met een voltooide opleiding en de mensen die zich op dit moment niet aanbieden op de arbeidsmarkt. Uit de ormvang van de bruto stromen en de totale vraag naar apothekersassistenten kunnen de drie netto vraag- en aanbodcomponenten bepaald worden.

Er moet in de prognoses rekening gehouden worden met het feit dat vacatures in principe niet geschikt zijn om inzicht te krijgen in de totale vraag naar nieuwkomers. Zowel nieuwe arbeidsplaatsen als gevolg van een positieve uitbreidingsvraag als plaatsen die openvallen door vertrek van apothekersassistenten naar een andere baan of omdat ze helemaal stoppen met werken leiden tot een vacature. Deze vacatures moeten vervuld worden door nieuwe werknemers. Wanneer mensen worden aangetrokken die al werkzaam zijn als apothekersassistent laten deze op hun beurt weer een open plek achter, die ook weer opgevuld moet worden. Uiteindelijk is er een nieuwe apothekersassistent nodig die geen open plek achterlaat. Zoals al eerder in hoofdstuk 2 is opgemerkt, wordt een dergelijke opeenvolging van vacatures een vacatureketen genoemd. Deze keten wordt pas gesloten wanneer een vacature word't vervuld door iemand die geen vacature binnen de sector achterlaat. Door het bestaan van zo'n vacatureketen is het aantal vacatures dat ontstaat als het gevolg van het vertrek van een apothekersassistent veel groter dan het feitelijk aantal nieuwe apothekersassistenten dat nodig is. Voor de prognose van de toekomstige arbeidsmarktstudie is echter uitsluitend het aantal nieuwe apothekersassistenten dat nodig is om de diverse ketens te sluiten van belang. Het tellen van alle vacatures zou derhalve een overschatting betekenen van het feitelijk aantal nieuwe apothekersassistenten dat nodig is. Deze overschatting wordt vanzelfsprekend ernstiger naarmate de vacatureketens langer zijn.

Tegenover het totale aantal baanopeningen voor nieuwkomers staat het totale aanbod dat wordt bepaald door de reeds op de markt aanwezige werklozen alsmede de instroom van schoolverlaters op de arbeidsmarkt voor apothekersassistenten. De verhouding tussen vraag en aanbod op de arbeidsmarkt leidt tot een gunstig of ongunstig arbeidsmarktperspectief voor de opleiding tot apothekersassistent. Zodra de stroom aan schoolverlaters te groot is om het aantal werkenden op het gewenste peil te houden, zullen schoolverlaters ofwel werk moeten zoeken in een ander beroep, ofwel werkloos worden. Zo kan ook het aantal beschikbare baanopeningen voor nieuwkomers groter worden dan de instroom. In dat geval zal er sprake zijn van een krapte op de arbeidsmarkt. Deze zou door de apotheken opgevangen kunnen worden door perso- 
neel te werven uit groepen op de arbeidsmarkt waar voorheen niet geworven werd. Ook is het mogelijk om de aantrekkingskracht van het beroep te vergroten of het personeelsverloop te verminderen.

\subsection{Ontwikkelingen in het aantal receptregels}

Als er een prognose van de vraag naar apothekersassistenten gemaakt moet worden, is er allereerst een prognose van de omvang van de werkgelegenheid nodig. In navolging van eerder onderzoek (De Wolf e.a., 1997) is er voor gekozen om de werkgelegenheid te koppelen aan het aantal geleverde receptregels. Het aantal receptregels wordt verklaard uit factoren als bevolkingsgroei, vergrijzing en de effecten van door de overheid gevoerde volumepolitiek. Met behulp van prognoses over deze factoren kan dan een voorspelling gemaakt worden van het aantal receptregels in de toekomst.

Tabel 3.1

Groej van het aantal receptregels, effecten van het overheidsbeleid, en de demografische ontwikkelingen, 1989 - 1996

\begin{tabular}{|c|c|c|c|c|}
\hline & \multirow{2}{*}{$\begin{array}{l}\text { Groei aantal } \\
\text { receptregels }\end{array}$} & \multirow{2}{*}{$\begin{array}{l}\text { Volume-effect } \\
\text { overheidsbeleid }\end{array}$} & \multicolumn{2}{|c|}{ Demografische factoren } \\
\hline & & & Bevolking (mln) & $65+(\%)$ \\
\hline 1989 & 5 & - & 14,8 & 12,7 \\
\hline 1990 & 6 & - & 14,9 & 12,8 \\
\hline 1991'a) & 10 & 5,0 & 15,0 & 12,9 \\
\hline 1992 & 5 & - & 15,1 & 13,0 \\
\hline 1993 & 3 & $-3,4$ & 15,2 & 13,0 \\
\hline 1994 & -6 & $-6,9$ & 15,3 & 13,1 \\
\hline 1995 & 0 & - & 15,4 & 13,2 \\
\hline 1996 & 2 & $-2,1$ & 15,5 & 13,3 \\
\hline 1997 & 2 & $-1,1$ & 15,6 & 13,4 \\
\hline 1998 & 5 & - & 156 & 13,5 \\
\hline
\end{tabular}

a) Het volume-effect overheidsbeleid voor dit jaar is een schatting.

Bron: SBAIKNMP/SFK/CBS

Tabel 3.1 geeft de ontwikkeling in de afgelopen 10 jaar van het aantal receptregels en de demografische factoren waarmee deze samenhangt. De totale groei van het aantal receptregels bedroeg in de periode 1989 - $199836 \%$, dat komt neer op een gemiddelde groei van $3,1 \%$ per jaar. Voor de prognoses wordt de totale feitelijke groei in een aantal componenten verdeeld. Allereerst is dat de structurele groei, namelijk de groei zoals deze zich zou hebben voorgedaan zonder overheidsingrijpen. Daamaast is er de 'incidentele groei' als gevolg van overheidsmaatregelen. De structurele groei wordt veroorzaakt door twee factoren, aan de ene kant de groei vanwege de demografische ontwikkeling, aan de andere kant dat wat hier 'autonome groei' genoemd wordt, namelijk de stijging van het medicijngebruik per hoofd van de bevolking. Deze autonome groei kan voor een groot deel verklaard worden uit de toenemende welvaart, waardoor men steeds meer geld over heeft voor zijn gezondheid (Zie ook Groot, 1998). Het gevolg hiervan is dat er steeds meer vraag is naar bestaande medicijnen, maar ook dat er een continue tendens is naar het ontwikkelen en gebruiken van nieuwe medicijnen. 
In de tweede kolom van de tabel is te zien hoe groot de volume-effecten (de incidentele groei) van de diverse overheidsmaatregelen geweest zijn. In 1991 is de prescriptieregeling van kracht geworden. Deze regeling heeft het aantal medicijnen dat per recept geleverd mag worden aan een maximum gebonden. Dit heeft een eenmalige stijging van het aantal receptregels tot gevolg gehad omdat er vanaf 1991 meerdere recepten nodig zijn voor medicijnen die voor die tijd op één recept geleverd mochten worden. Het is echter niet bekend hoe groot de groei geweest zou zijn zonder deze regeling. In 1993 zijn de homeopathische middelen uit het AWBZ-pakket verwijderd. Volgens cijfers van de SFK betrof dit in 1992 3,4\% van het totaal aantal voorschriften ${ }^{5}$. Per 1 januari 1994 werd het AWBZ-pakket verder uitgedund: diverse zelfzorgmiddelen kwamen niet langer voor vergoeding in aanmerking. Deze categorie medicijnen was in 1993 goed voor 6,9\% van het totaal aantal voorschriften. Per 1 april 1996 is in het kader van een opschoningsoperatie die bekend staat als de 'Trechter van Duning' het wettelijk verzekerde geneesmiddelenpakket verder terug gebracht. Deze uitdunning betrof een groep medicijnen die in $19952,1 \%$ van het totale aantal voorschriften bedroeg. Sinds 1997 wordt het griepvaccinatieprogramma niet langer uitgevoerd door de openbare apotheken. Hierdoor worden er geen griepvaccins meer via de openbare apotheek geleverd. Het aantal griepvaccins dat in 1996 geleverd werd, bedroeg $1,1 \%$ van het totaal aantal voorschriften. Als deze overheidsmaatregelen niet genomen zouden zijn, zou de totale groei over de afgelopen 10 jaar ongeveer $14,1 \%$ hoger geweest zijn, en daarmee uitgekomen zijn op ca. $55,1 \%$, ongeveer $4,5 \%$ op jaarbasis. Deze cijfers geven echter een overschatting van de groei van het geneesmiddelengebruik, omdat er geen rekening gehouden wordt met de extra groei van het aantal recepten als gevolg van de prescriptieregeling. De SFK is helaas niet in staat aan te geven welk deel van de groei in 1991 een gevolg geweest is van de prescriptieregeling. Omdat er echter bekend is dat de aangegeven groei een overschatting is, wordt er hier van uit gegaan dat de feitelijke groei in $19915 \%$ bedroeg $^{6}$. Dit betekent dat zonder overheidsingrijpen de feitelijke groei van het medicijnverbruik over de afgelopen jaren $48,7 \%$ zou hebben bedragen, dat is ca. $4,0 \%$ op jaarbasis.

Voor het maken van de prognoses is het nodig de totale structurele groei toe te wijzen aan demografische factoren en aan de autonome groei van het aantal medicijnen dat per persoon gebruikt wordt. Als we uitgaan van het feit dat 65-plussers gemiddeld drie maal zoveel medicijnen (gemeten in aantal receptregels) gebruiken, valt uit de derde en de vierde kolom in tabel 3.1 af te leiden dat over de afgelopen jaren $7,0 \%$ van de totale groei toe te wijzen valt aan demografische factoren: $5,6 \%$ aan de bevolkingsgroei en $1,3 \%$ aan de vergrijzing. Dat betekent dat de resterende groei verklaard moet

5. Het verbruik van homeopathische geneesmiddelen groeide sneller dan het totale aantal receptregels ( $29 \%$ in 1991 en $9 \%$ in 1992). Naast het eenmalige effect op de groei van het medicijngebruik dat deze verwijdering uit het pakket tot gevolg heeft gehad, zal er derhalve ook sprake zijn van een licht remmend effect op de groei in latere jaren.

6. Deze waarde is gekozen omdat in de jaren waarin de overheid geen ingreep gepleego heeft de groei van het medicijngebruik $5 \%$ bedroeg. 
worden uit een toenemend medicijngebruik per hoofd van de bevolking. Dit houdt in dat deze trendmatige autonome groei per hoofd van de bevolking over de afgelopen jaren $39,3 \%$ bedroeg, dat is ca. $3,5 \%$ per jaar. Duidelijk is dat deze trendmatige groei de meest bepalende factor is van de totale groei.

\subsection{Vraag naar apothekersassistenten in de openbare apotheken}

Zoals in paragraaf 3.2 werd aangegeven, is de vraag naar apothekersassistenten de optelsom van de uitbreidingsvraag en de vervangingsvraag. De uitbreidingsvraag ontstaat als gevolg van de verandering in de werkgelegenheid voor apothekersassistenten in de openbare apotheek, de vervangingsvraag ontstaat vanwege het feit dat er mensen stoppen met werken, of buiten de apotheek gaan werken. In deze paragraaf zullen prognoses voor beide componenten van de totale vraag naar nieuwkomers alsmede het totaal aantal baanopeningen in de periode 1998 - 2006 worden gepresenteerd.

\section{Uitbreidingsvraag}

Voor de modeliering van de vraag naar apothekersassistenten in de openbare apotheek wordt eerst een prognose gemaakt van het aantal recepten dat de komende jaren verwerkt zal moeten worden door de openbare apotheken. Uitgangspunt hierbij zijn de bevindingen uit de vorige paragraaf. Hier werden drie factoren besproken die de omvang van het aantal receptregels in de komende jaren bepalen: bevolkingsomvang, vergrijzing en autonome groei. Op basis van de bevolkingsprognoses van het CBS kunnen de demografische factoren in de verwachte groei verwerkt worden. In tabel 3.2 staan de prognoses van de bevolkingsomvang en de vergrijzingsgraad aangegeven. Daamaast gaat het basisscenario uit van de in paragraaf 3.3 afgeleide autonome groei van het aantal recepten per hoofd van de bevolking van 3,5\% per jaar. Dat betekent dat het basisscenario uitgaat van de situatie waarin de overheid geen volumebeperkende maatregelen meer zal invoeren. Deze keuze is gemaakt omdat enerzijds bekend is dat het gevoerde overheidsbeleid grote invloed heeft op de arbeidsmarktsituatie, maar anderzijds ook zeer moeilijk voorspelbaar is. Het basisscenario gaat daarom uit van een situatie zonder overheidsingrijpen, terwijl in het volgende hoofstuk door middel van een aantal gevoeligheidsanalyses getoond zal worden in hoeverre de uitkomsten van het basisscenario gevoelig zijn voor afwijkende veronderstellingen ten aanzien van de groei van het medicijngebruik. Het aantal receptregels moet vertaald worden naar het aantal benodigde apothekersassistenten. De methodiek die we daarbij volgen is overgenomen van De Wolf e.a. (1997). Op basis van de historische gegevens bepalen we de verhouding tussen het aantal geleverde receptregels en het aantal uren dat er gewerkt is. Door de verwachte aantallen receptregels te delen door deze factor krijgen we inzicht in het aantal uren dat er in de toekomst gewerkt zal moeten worden. De op deze manier bepaalde productiviteit ligt tussen de 6,1 recepten per uur (in 1989) en de 7,1 recepten per uur (in 1992). Het niveau in 1996 is 6,5. Omdat er uit de historische gegevens blijkt dat er een zekere samenhang bestaat tussen de aanwezigheid van knelpunten op de 
arbeidsmarkt en de hoogte van deze productiviteit, gaan we er van uit dat in geval van tekorten aan apothekersassistenten deze productiviteit weer langzaam op kan lopen tot 7 recepten per uur. Dit omdat we er van uitgaan dat veranderingen in de hoeveelheid werk voor een bepaalde apotheek niet geheel door zullen werken in het aantal apothekersassistenten dat in de desbetreffende apotheek werkzaam is. Deze gedeeltelijke afwenteling staat in de economische literatuur bekend als 'labour hoarding' (zie b.v. De Koning, 1987).

Ten slotte kan uit het aantal uren dat gewerkt moet worden het aantal benodigde apothekersassistenten bepaald worden. Hiervoor is het nodig om te weten wat het gemiddeld aantal uren is dat per week gewerkt wordt. We gaan er in dit basisscenario van uit dat er de komende jaren nog maar in zeer beperkte mate sprake zal zijn van een verdere afname van de gemiddelde werkweek van apothekersassistenten van 27,7 uur per week in 1998 tot 27,5 uur per week in 2006. Deze veronderstelling is gebaseerd op het feit dat er de afgelopen jaren in toenemende mate in deeltijd gewerkt werd. Het CPB gaat in zijn scenario's uit van een afname van de voltijdse werkweek met ongeveer een half procent per jaar. Dat zou impliceren dat de gemiddelde werkweek in 2006 ongeveer 26,7 uur zou bedragen. Vanwege de tekorten aan personeel (zie paragraaf 3.6) zal de daling van de gemiddelde werkweek bij de apothekersassistenten waarschijnlijk minder sterk zijn.

Door deze aannamen te kiezen wordt in deze prognoses, zoals gezegd, geen rekening gehouden met het feit dat de overheid net zoals in het verleden eenmalige maatregelen zal nemen om het volume - en daarmee de kosten - van het medicijngebruik te beperken. Ook wordt er geen rekening gehouden met de mogelijke effecten van veranderingen in het aantal distributiepunten. Hierbij kunnen we denken aan het vergroten van het aantal distributiepunten omdat bijvoorbeeld de ziekenhuisapotheken ook mogen gaan leveren aan patiënten die niet in het ziekenhuis opgenomen zijn. Wanneer er bij de vergroting van het aantal distributiepunten ten opzichte van het medicijnverbruik sprake is van 'schaalnadelen' zal dit mogelijk een extra toename van de vraag naar apothekersassistenten tot gevolg hebben, zelfs als de totale vraag naar medicijnen gelijk blijft.

Tabel 3.2 geeft een overzicht van de prognoses voor de uitbreidingsvraag volgens het basisscenario. Deze tabel geeft allereerst een overzicht van de verwachte bevolkingsomvang en de mate van vergrijzing. Deze cijfers zijn gebaseerd op de bevolkingsprognoses van het CBS. In de derde kolom staat de verwachte groei van het aantal receptregels. Hierbij is uitgegaan van een veronderstelde autonome groei van $3,5 \%$. Het blijkt dat onder onze veronderstellingen de groei van het aantal receptregels rond de $4 \%$ per jaar ligt. Dit is iets lager dan de afgelopen jaren, voomamelijk vanwege het feit dat de effecten van de demografische factoren kleiner zullen zijn dan in de afgelopen jaren. De totale groei over de komende negen jaar zal uitkomen op $44 \%$. In de vierde kolom staat de verwachte werkgelegenheid voor apothekersassistenten. Vanwege de verwachte tekorten aan apothekersassistenten (zie tabel 3.6 ) is bij de bepaling van de 
uitbreidingsvraag rekening gehouden met een toenemende productiviteit. Ook is de lichte afname van de gemiddelde werkweek in de uitbreidingsvraag verwerkt. In de laatste kolom staat de prognose voor de verwachte uitbreidingsvraag. Het blijkt dat het aantal mensen dat per jaar nodig is zal toenemen, van 470 in 1998 tot 570 in 2006. In totaal zal de uitbreidingsvraag over deze periode 4.690 bedragen, dat is ongeveer $41 \%$ van het totaal aantal werkzamen op 1 januari 1998. De groei van het aantal receptregels en van de werkgelegenheid houden dus gelijke tred. Deze stijging van de werkgelegenheid is vergelijkbaar met de werkgelegenheidsgroei in de afgelopen jaren: over de periode 1992 - 1996 is volgens gegevens van de KNMP het aantal werkzame apothekersassistenten in totaal met $15 \%$ gestegen?

Tabel 3.2

Verwachte demografische ontwikkelingen en werkgelegenheid voor apothekersassistenten, $1998-2006$

\begin{tabular}{lccccc}
\hline & $\begin{array}{c}\text { Bevolking } \\
(\mathrm{mln})\end{array}$ & $\begin{array}{c}\text { Aandeel 65+ } \\
\%\end{array}$ & $\begin{array}{c}\text { Groei aantal } \\
\text { recepten } \\
\%\end{array}$ & $\begin{array}{c}\text { Werkgele- } \\
\text { genheid } \\
\text { (personen) }\end{array}$ & $\begin{array}{c}\text { Uitbreidings- } \\
\text { vraag } \\
\text { (personen) }\end{array}$ \\
\hline & & & & & 470 \\
1998 & 15,6 & 13,5 & 4,0 & 11.370 & 480 \\
2000 & 15,7 & 13,6 & 4,0 & 11.840 & 500 \\
2001 & 15,8 & 13,6 & 4,0 & 12.330 & 510 \\
2002 & 15,9 & 13,7 & 3,9 & 12.820 & 520 \\
2003 & 16,0 & 13,8 & 3,9 & 13.330 & 530 \\
2004 & 16,0 & 13,8 & 3,9 & 13.850 & 550 \\
2005 & 16,1 & 14,0 & 3,9 & 14.390 & 560 \\
2006 & 16,2 & 14,1 & 3,8 & 14.930 & 570 \\
Totaal & 16,2 & 14,2 & 3,8 & 15.490 & 4.690 \\
\hline
\end{tabular}

Bron: CBS/ROA

\section{Vervangingsvraag}

De tweede component van de vraag naar personeel is de vervangingsvraag. Door de uitstroom van werknemers ontstaan er vacatures die opgevuld moeten worden. Voor een deel worden die vacatures opgevuld door mensen die al elders als apothekersassistent werkzaam zijn. Deze mobiliteit binnen de sector leidt, zoals in paragraaf 3.2 reeds werd aangegeven, niet tot baanopeningen voor nieuwkomers maar slechts tot een vacatureketen. Het meetellen van alle vacatures leidt daardoor tot een overschatting van het benodigde aantal apothekersassistenten. Om dit probleem op te lossen wordt er gebruik gemaakt van een stromenmodel. Gegeven het personeelsbestand aan het begin van een kalenderjaar geeft dit model een prognose van de bruto

7. Doortrekken van deze trend zou leiden tot een omvang van het personeelsbestand op 1 januari 2007 van ruim 15.000 assistenten, hetgeen iets kleiner is dan het aantal dat in deze prognose als uitgangspunt wordt gebruikt. In hoofdstuk 4 zal getoond worden wat de tekorten zullen zijn als de groei afwijkt van de in het basisscenario veronderstelde niveau. 
uitstroom, dat wil zeggen van het aantal apothekersassistenten waarvan het dienstverband in dat kalenderjaar zal eindigen. Daamaast geeft het model een prognose voor het aantal apothekersassistenten dat doorstroomt naar een andere openbare apotheek. Het saldo van deze twee stromen - bruto uitstroom minus doorstroom - geeft de netto vervangingsvraag: het aantal plaatsen dat opgevuld moet worden door nieuwkomers op de arbeidsmarkt en herintreders.

Het model geeft aan wie er in de loop van het jaar uitstroomt. Ook is bekend uit de instroomprognoses - die in de volgende paragraaf nader besproken zullen worden wie er in de loop van het jaar is gaan werken als apothekersassistent. Het is dus bekend wat aan het eind van het jaar het aantal werkende apothekersassistenten is en wat de samenstelling van deze groep is naar leeftijd en ervaring. Op basis van deze informatie kunnen voor het volgende jaar opnieuw de uitstroom, de doorstroom en de vervangingsvraag bepaald worden. Op deze manier kan een prognose gemaakt worden voor een reeks van jaren. Omdat er een schatting gemaakt moet worden van de kenmerken van de werkende apothekersassistenten aan het begin van ieder kalenderjaar, verliezen de prognoses van jaar op jaar iets van hun nauwkeurigheid. Bovendien kunnen in de loop van de jaren ook de relaties tussen leeftijd, ervaring en uitstroomkans waarop het model gebaseerd is, veranderen. Ook dit maakt dat de prognoses, naarmate ze betrekking hebben op een langere periode, een toenemende mate van onzekerheid krijgen. Het is daarom raadzaam niet verder dan vijf tot tien jaar vooruit te voorspellen, en om de prognoses regelmatig aan te passen aan de hand van nieuw beschikbare informatie.

In tabel 3.3 staan de prognoses voor de uitstroom, doorstroom en vervangingsvraag voor de periode 1998 - 2006 gegeven. Bij de uitstroomprognoses valt op dat de omvang van de bruto uitstroom toeneemt, van 1.060 in 1998 tot 1.330 in 2006. Omdat in deze periode het aantal werkenden toeneemt van 11.370 in 1998 tot 15.490 in 2006 , loopt de procentuele uitstroom terug van ruim $9 \%$ tot bijna $8 \%$ van het aantal werkenden. Dit is een gevolg van het feit dat een steeds groter deel van met name de gehuwde vrouwen langer in de apotheek blijft werken. Dit is ook te zien als gekeken wordt naar de ontwikkeling van de gemiddelde leeftijd. Momenteel is de gemiddelde leeftijd van apothekersassistenten ongeveer 34 jaar; in 2006 zal dat toegenomen zijn tot bijna 37 jaar. Datzelfde geldt voor de lengte van het dienstverband. Op basis van de nu waargenomen uitstroom gerelateerd aan de lengte van het dienstverband is te verwachten dat ook de gemiddelde lengte van het dienstverband zal toenemen: van momenteel bijna zes jaar tot ongeveer acht jaar in het jaar 2006. 


\begin{tabular}{lrcc}
\hline & Uitstroom & Doorstroom & Vervangingsvraag \\
\hline 1998 & 1.060 & 520 & 550 \\
1999 & 1.070 & 520 & 550 \\
2000 & 1.100 & 510 & 580 \\
2001 & 1.140 & 530 & 610 \\
2002 & 1.170 & 550 & 630 \\
2003 & 1.210 & 540 & 660 \\
2004 & 1.250 & 550 & 690 \\
2005 & 1.290 & 560 & 710 \\
2006 & 1.330 & 620 & 730 \\
Totaal & 10.620 & 4.910 & 5.700 \\
\hline
\end{tabular}

Bron: ROA

Dat men gedurende langere tijd blijft werken in de apotheek heeft ook een effect op de doorstroom: het blijkt dat als mensen langer als apothekersassistent werkzaam zijn, ze minder vaak doorstromen naar een andere baan als apothekersassistent. Ook dit is terug te zien in de prognoses: van de bruto uitstroom heeft een steeds kleiner deel betrekking op de doorstroom van de ene apotheek naar een andere. De omvang van de doorstroom is ongeveer $46 \%$ van de bruto uitstroom. Al met al wordt verwacht dat de vervangingsvraag de komende negen jaar stijgt van 550 in 1998 tot 730 per jaar in 2006. Als percentage van de omvang van het personeelsbestand bilift de vervangingsvraag ongeveer gelijk, ruim $4,5 \%$ op jaarbasis.

\section{Baanopeningen}

De baanopeningen voor nieuwkomers (en herintreders) worden gevormd door de som van de uitbreidingsvraag en de vervangingsvraag. In tabel 3.4 staat voor de prognoseperiode aangegeven welke aantallen baanopeningen er voor nieuwkomers en herintreders verwacht worden. De komende jaren neemt zowel de uitbreidingsvraag als de vervangingsvraag toe. De som van deze beiden, de baanopeningen, neemt dus ook toe. Als gevolg van de relatief afnemende uitstroom neemt het aantal baanopeningen als percentage van het totaal aantal werkenden overigens licht af, van $9 \%$ in 1998 , tot $8 \%$ in 2006 . De verschillen in de groei van het aantal baanopeningen van jaar tot jaar zijn vrij beperkt.

Het valt op dat de vervangingsvraag de grootste invloed heeft op het totaal aantal baanopeningen: bijna $55 \%$ van de baanopeningen is toe te schrijven aan de vervangingsvraag. Dit percentage is echter aanzienlijk lager dan het percentage dat gevonden wordt door Borghans e.a. (1998). In die studie wordt aangegeven dat voor de periode 
tot 2007 ongeveer $75 \%$ van de baanopeningen voor MBO-ers toe te schrijven is aan de vervangingsvraag ${ }^{8}$.

Tabel 3.4

Baanopeningen voor nieuwkomers, 1998 - 2006

\begin{tabular}{lccc}
\hline & Uitbreidingsvraag & Vervangingsvraag & Baanopeningen \\
\hline 1998 & 470 & 550 & 1.020 \\
1999 & 480 & 550 & 1.040 \\
2000 & 500 & 580 & 1.080 \\
2001 & 510 & 610 & 1.120 \\
2002 & 520 & 630 & 1.150 \\
2003 & 530 & 660 & 1.190 \\
2004 & 550 & 690 & 1.230 \\
2005 & 560 & 710 & 1.270 \\
2006 & 570 & 730 & 1.300 \\
Totaal & 4.690 & 5.700 & 10.390 \\
\hline
\end{tabular}

Bron: ROA

\subsection{Aanbod van apothekersassistenten}

Tegenover de baanopeningen voor gediplomeerde apothekersassistenten staat de instroom op de arbeidsmarkt van apothekersassistenten. Daarbij kan een aantal groepen onderscheiden worden. Allereerst zijn dat de schoolverlaters. Daarnaast zijn er herintreders en mensen met een opleiding tot apothekersassistent die voorheen buiten hun vak specifieke beroepsterrein werkzaam waren.

\section{Schoolverlaters}

De prognoses voor de arbeidsmarktinstroom van gediplomeerde apothekersassistenten zijn gebaseerd op een drietal bronnen. Allereerst zijn er de gegevens van de SBA, waaruit bekend is hoeveel gediplomeerden er de afgelopen jaren op de arbeidsmarkt zijn ingestroomd. Daamaast zijn er ciffers afkomstig uit de Referentieramingen van het Ministerie van Onderwijs, Cultuur en Wetenschappen, die een prognose geven van de aantallen schoolverlaters voor de komende tien jaar. Ten slotte geeft de RUBS-enquête van het ROA aan in hoeverre de gediplomeerde apothekersassistenten terecht komen in de openbare apotheek.

8. Dit verschil wordt voor een groot deel bepaald door de hogere uitbreidingsvraag in het hier geschetste basisscenario. Borghans e.a. gaan uit van een verwachte groei van de werkgelegenheid die in belangrijke mate is gerelateerd aan het feitelijk waargenomen gemiddetde over de afgelopen jaren, terwijl hier wordt uitgegaan van een uitbreidingsvraag op basis van de structurele groei van het medicijngebruik. 
In de inleiding van dit rapport is gesteld dat beroepen als apothekersassistent, die gekenmerkt worden door een zeer nauwe aansluiting tussen opleiding en beroep, te maken kunnen krijgen met een zogenaamde varkenscyclus. Dit houdt in dat tekorten op de arbeidsmarkt met enige vertraging zullen leiden tot toenemende aantallen studenten, hetgeen weer zal leiden tot overschotten. Als gevolg van dergelijke processen zal zowel het aantal leerlingen op de opleidingen fluctueren, als ook het percentage dat na het voltooien van de opleiding in de openbare apotheek wil werken. Een andere bron van fluctuatie in de arbeidsmarktinstroom is het aantal baanopeningen voor de afgestudeerden dat er op andere plaatsen bestaat. Een sterke toename van de werkgelegenheid in de ziekenhuisapotheken of de industrie zou zo'n bron van fluctuaties kunnen zijn. Er kan echter op basis van de nu bekende gegevens niet afgeleid worden of dergelijke processen zich zullen voordoen. Bovendien kan worden verwacht dat een verschuiving van zowel vraag als aanbod naar ziekenhuisapotheken geen groot effect zal hebben op de arbeidsmarktstudie voor apothekersassistenten. In dit rapport is er daama voor gekozen om de effecten van deze processen niet in de prognoses mee te nemen.

De Referentieramingen geven alleen prognoses voor een bredere groep van opleidingen. Uit deze ramingen zijn ook de gegevens van de afgelopen jaren bekend. De prognose van het aantal schoolverlaters is gebaseerd op het verwachte aantal schoolverlaters in de richting (M)DGO/MBO assistent gezondheidszorg. Binnen deze richting vallen ook de dokters- en tandartsassistenten. Op basis van de schoolverlatersgegevens van de SBA is bekend welk deel van de leerlingen uit deze grotere groep de opleiding tot apothekersassistent gevolgd hebben. Door te veronderstellen dat dit deel constant zal blijven in de komende jaren, kan op basis van de Referentieramingen een prognose gemaakt worden van de aantallen schoolverlaters van de opleiding tot apothekersassistent.

In dit rapport is echter niet de hele groep van gediplomeerde apothekersassistenten van belang, maar uitsluitend dat deel dat zich richt op een baan in de openbare apotheek. Er zal dus een prognose gemaakt moeten worden van het percentage schoolverlaters dat een baan zoekt als apothekersassistent in de openbare apotheek. In hoofdstuk 2 bleek dat de afgelopen jaren ongeveer $70 \%$ van diegenen die in dit jaar geslaagd zijn voor hun diploma apothekersassistent binnen een jaar na afstuderen een baan als apothekersassistent heeft gevonden. Bij de aanduiding schoolverlater moet hier.wel bedacht worden dat ongeveer $10 \%$ van de groep die zijn diploma haalt aansluitend verder studeert. Deze groep is dus eigenlijk geen schoolverlater in die zin dat ze zich aanbieden op de arbeidsmarkt. In de prognoses gaan we er van uit dat het percentage van de gediplomeerden dat binnen een jaar werk als apothekersassistent zoekt ongewijzigd blijft. Met andere woorden, het aanbod dat zich richt op een functie binnen de openbare apotheek bedraagt $70 \%$ van het (verwachte) aantal gediplomeerden van de opleiding tot apothekersassistent. Deze manier om afgestudeerden aan een sector toe te wijzen is niet geheel zonder nadelen. De vraag welk deel van de afgestudeerden een baan in de apotheek vindt, hangt namelijk niet alleen af van het aanbod van schoolver- 
laters, maar ook van een aantal vraagfactoren. Misschien heeft een veel groter deel van de schoolverlaters de afgelopen jaren een baan gezocht als apothekersassistent, maar die niet gevonden. Het feit dat $70 \%$ een baan in de apotheek gevonden heeft, wil niet zeggen dat alleen deze schoolverlaters gezocht hebben naar een dergelijke baan. Mogelijk wordt het aanbod van schoolverlaters derhalve onderschat. Aan de andere kant, de openbare apotheek is niet de enige werkgever voor de gediplomeerde apothekersassistenten. Als schoolverfaters er de voorkeur aan geven om bij de industrie of een ziekenhuisapotheek te werken, maar juist daar de werkgelegenheid te kort schiet, is het oorspronkelijke aanbod voor de openbare apotheken juist kleiner dan de waargenomen $70 \%$ : als de werkgelegenheid in de ziekenhuisapotheken zou groeien, zou men daar gaan werken, en niet in de openbare apotheek. In dat geval is er derhalve sprake van een overschatting van het aanbod.

Tabe/ 3.5

Schoolverlaters in de periode $1998-2006$

\begin{tabular}{lcc}
\hline & Schoolverlaters & $\begin{array}{l}\text { Werkzoekend } \\
\text { in apotheek }\end{array}$ \\
\hline 1998 & 720 & 500 \\
1999 & 710 & 500 \\
2000 & 760 & 530 \\
2001 & 750 & 530 \\
2002 & 740 & 520 \\
2003 & 760 & 530 \\
2004 & 770 & 540 \\
2005 & 790 & 560 \\
2006 & 810 & 560 \\
Totaal & 6.810 & 4.770 \\
\hline
\end{tabular}

Bron: ROA

In tabel 3.5 is aangegeven hoe groot naar verwachting het aantal schoolverlaters uit de opleiding tot apothekersassistent de komende jaren zal zijn. Het is te zien dat het aantal schoolverlaters, zij het met enige fluctuaties, zal stijgen van ongeveer 720 in 1998 tot 810 in 2006. In totaal zullen er in de jaren 1998 - 2006 circa 6.800 schoolverlaters van de opleiding tot apothekersassistent op de arbeidsmarkt instromen. In de tweede kolom van de tabel staan de verwachte aantallen schoolverlaters die zich zullen aanbieden op de markt voor apothekersassistenten in de openbare apotheek.

\section{Overige instroom}

De schoolverlaters zijn niet de enige groep op de arbeidsmarkt waaruit personeel geworven kan worden. Zoals in hoofdstuk 2 reeds werd aangegeven, bestaat er een groep werklozen met de opleiding tot apothekersassistent. Ook bestaat er een vrij grote 'stille reserve' van niet-participerende vrouwen die ooit als apothekersassistent gewerkt hebben. Deze gediplomeerden zouden in principe (misschien na een bijscholing of opfris- 
cursus) weer aan het werk kunnen als apothekersassistent. Op basis van de beschikbare gegevens is het niet mogelijk om aan te geven wat precies de kenmerken van deze mensen zijn, en wat er toe zou kunnen leiden dat een deel van hen zich weer aanbiedt op de arbeidsmarkt. Het is ook niet duidelijk of deze mensen vanwege hun enigszins verouderde kwalificaties alleen aangenomen worden bij gebrek aan schoolverlaters, of dat apatheken juist de voorkeur geven aan 'ervaren' herintreders boven schoolverlaters. Bovendien is het onduidelijk of deze potentiële herintreders in de praktijk wel op zoek zijn naar een baan. Dit maakt het onmogelijk om tot een goede inschatting van het aantal instromers uit deze stille reserve te komen.

Verondersteld wordt daarom dat baanopeningen in eerste instantie vervuld worden door schoolverlaters die zich aanbieden op de markt voor apothekersassistenten. De resterende baanopeningen worden vervuld door werklozen en door arbeidskrachten uit de stille reserve. Dit houdt in dat we deze laatste instroom beschouwen als een restcategorie die zich niet actief aaribiedt op de arbeidsmarkt. We gaan er dus van uit dat apothekers bij de werving van personeel er de voorkeur aan geven om een jongere, pas afgestudeerde apothekersassistent in dienst te nemen in plaats van op zoek te gaan naar een oudere apothekersassistent die een loopbaanonderbreking heeft gehad, geruime tijd buiten de apotheek gewerkt heeft, of werkloos is geweest.

\subsection{Verwachte knelpunten op de arbeidsmarkt}

Met de prognoses van baanopeningen en arbeidsmarktinstroom die in de vorige twee paragrafen zijn gepresenteerd is het mogelijk om vraag en aanbod met elkaar te confronteren. Dit geeft een indicatie van het te verwachten tekort of overschot aan personeel. Tabel 3.6 geeft een overzicht van deze confrontatie van de baanopeningen voor nieuwkomers en de verwachte schoolvertatersinstroom. De derde kolom geeft het saldo aan. Uit de tabel blijkt duidelijk dat er in het basisscenario forse tekorten op zullen gaan treden. In de eerste jaren zal er sprake zijn van een tekort van $51 \%$ van het totaal aantal baanopeningen. De omvang van het tekort loopt zelfs op tot $56 \%$ van het aantal baanopeningen in 2006. Het zal dus in toenemende mate moellijker worden om personeel te vinden.

De omvang van de jaarlijkse tekorten is ruim $4 \%$ van het totaal aantal werkenden. Bij vergelijking van tabel 3.3 en tabel 3.6 valt op dat de netto uitstroom ongeveer even groot is als de tekorten die in het basisscenario worden verwacht. Omdat vrijwel niemand van de uitstromende apothekersassistenten de pensioengerechtigde leeftijd heeft, zou het langer vasthouden van het personeel een effectief middel kunnen zijn om de tekorten te verminderen. Het volledig oplossen van de tekorten door dit soort maatregelen is echter geen haalbare optie, omdat hiervoor de personeelsuitstroom in feite geheel gestopt zou moeten worden. Ook was er in 1997 nog een grote stille reserve aan apothekersassistenten van bijna 10.000 personen aanwezig. Daamaast was er in het verleden ook een instroom van herintreders ( $14 \%$ van de totale instroom, zie tabel 
2.2). Door de aanwezigheid van deze stille reserve en de mogelijkheid om hier personeel te werven, bestaat er nog een manier om de tekorten te verminderen. De praktijk moet uitwijzen of deze beide mogelijkheden voldoende zijn om de tekorten het hoofd te bieden. Makkelijk zal het niet zijn, want het totale tekort is ruim de helft van de in 1997 aanwezige stille reserve.

Tabel 3.6

Vraag en aanbod van apothekersassistenten, 1998 - 2006

\begin{tabular}{lccc}
\hline & Baanopeningen & Schoolverlaters & Tekort $^{\text {a) }}$ \\
\hline 1998 & 1.020 & 500 & 520 \\
1999 & 1.040 & 500 & 540 \\
2000 & 1.080 & 530 & 550 \\
2001 & 1.120 & 530 & 590 \\
2002 & 1.150 & 520 & 620 \\
2003 & 1.190 & 530 & 660 \\
2004 & 1.230 & 540 & 690 \\
2005 & 1.270 & 560 & 710 \\
2006 & 1.300 & 560 & 740 \\
& & & 5.620
\end{tabular}

a) De jaarcijfers van de tekorten zijn niet cumulatief, maar geven aan welk tekort er in het desbetreffende jaar ontstaat.

Bron: ROA

\subsection{Vergelijking met eerdere prognoses}

In de vorige paragrafen is een prognose van de arbeidsmarktontwikkeling voor de apothekersassistenten in de openbare apotheek gepresenteerd. Omdat de resultaten in deze studie niet overeenkomen met de resultaten in de andere studies, is het goed om even stil te staan bij de overeenkomsten en verschillen met andere prognoses. In deze paragraaf wordt voor de uitbreidingsuraag een drietal prognoses naast de hier gepresenteerde gezet. Voor het aanbod wordt een vergelijking gemaakt met een eerder door het ROA (1997a) gemaakte prognose.

In De arbeidsmarkt naar opleiding en beroep tot 2002 (ROA, 1997a) is een prognose gemaakt voor de arbeidsmarktperspectieven van schoolverlaters van diverse opleidingen en beroepen. Ook de opleiding tot en het beroep van apothekersassistent is hierin opgenomen. Binnen de beroepenclassificatie die het ROA hanteert, worden de apothekersassistenten echter samengenomen met de medisch analisten en enkele andere assisterende beroepen in de gezondheidszorg. Dit gebeurt vanwege de relatief kleine aantallen mensen die in deze beroepen werkzaam zijn. In 1996 waren er 33.500 mensen in deze beroepsgroep werkzaam, samen goed voor 27.500 arbeidsjaren. Het aantal werkenden in deze beroepsgroep is de taatste jaren constant. Ongeveer $44 \%$ van deze werkenden werkt in deeltijd, en dit percentage is stijgend. Het gemiddeld aantal uren per week dat gewerkt wordt is ongeveer 33 . Uit een vergelijking van deze cijfers met de in hoofdstuk 2 gepresenteerde blijkt dat de groep waarop de algemene ROA- 
prognose betrekking heeft van een andere samenstelling is dan de in dit rapport onderzochte.

In deze eerdere ROA-prognose is wel de opleiding tot apothekersassistent afzonderlijk beschouwd. Er zijn in 1996 ongeveer 16.000 mensen werkzaam met een opleiding $M B O / L W$ apothekersassistent die samen 11.500 arbeidsjaren vervullen. Uit de prognoses blijkt dat tot 2002 grote knelpunten verwacht worden bij de opleiding $M B O / L W$ apothekersassistent. Het verwachte aantal schoolverlaters zal namelijk te klein zijn om de beschikbare baanopeningen te vervullen. De door het ROA verwachte uitbreidingsvraag voor de opleiding zal 4.800 zijn voor periode 1997 - 2002, dat wil zeggen $28 \%$ van het aantal mensen dat nu werkzaam is. De vervangingsvraag is daarentegen volgens deze prognosestudie laag, namelijk 2.900 . Dit is $17 \%$ van degenen die momenteel werkzaam zijn. Het verwachte aantal baanopeningen voor de schoolverlaters wordt dus geschat op 7.700. Gerelateerd aan de verwachte instroom van schoolverlaters van 6.400 geeft dit aan dat er een tekort van circa 1.300 apothekersassistenten te ver-wachten valt tussen nu en 2002, dat is een tekort van ongeveer 250 per jaar. In de huidige prognose wordt een tekort voorspeld dat ruim twee keer zo hoog ligt. De belangrijkste verklaring voor dit verschil moet gezocht worden in de uitgangspunten ten aanzien van de werkgelegenheidsgroei. In ROA (1997a) wordt deze in principe gebaseerd op de verwachte sectorgroei zoals deze worden voorspeld door het $\mathrm{CPB}$. Een belangrijke component bij deze verwachte sectorgroei is de gemiddelde groel uit het verleden. In de huidige studie wordt niet deze gemiddelde groei, maar de structurele groei, dat is de gemiddelde groei gecorrigeerd voor de overheidsingrepen, als uitgangspunt genomen. Het gevolg hiervan is een verwachte groei die aanzienlijk hoger ligt dan die in ROA (1997a).

Naast dit verschil is er nog een aantal verschillen tussen de RCA (1997a) prognoses en de huidige aanpak aan te geven. De prognoses in ROA (1997a) richten zich op de totale werkgelegenheid voor gediplomeerde apothekersassistenten, en de huidige prognoses uitsluitend op de werkgelegenheid binnen de openbare apotheek. Er is dus een verschil in de onderzochte groep hetgeen zich ook weerspiegelt in de verwachte omvang van het aantal baanopeningen. In feite wordt dus in deze prognosestudie een groter tekort voorspeld dan in ROA (1997a). In de hier gepresenteerde prognoseresultaten is de uitbreidingsvraag veel kleiner dan de in De arbeidsmarkt naar opleiding en beroep tof 2002. In deze laatste studie wordt een uitbreidingsvraag van ongeveer 1.000 mensen per jaar voorspeld, tenwijl hier een uitbreidingsvraag van ruim 500 mensen per jaar wordt voorspeld. Dit verschil is ten dele schijn want het wordt voornamelijk veroorzaakt door het feit dat in de eerdere ROA-prognoses uitgegaan wordt van de totale werkgelegenheidsgroei voor de beroepsgroep, inclusief de groep die buiten de openbare apotheek werkzaam is. De vervangingsvraag wordt daarentegen lager ingeschat dan in dit rapport: de eerdere ROA-prognoses gaan uit van een veel sterkere participatiestijging van vrouwen, wat een sterk teruglopende uitstroom veroorzaakt. Daamaast wordt er in ROA (1997a) gecorrigeerd voor de instroom van herintreders, wat in de 
huidige prognoses niet wordt gedaan. De prognoses voor het aantal schoolverlaters is in beide prognoses uit dezelfde bron afkomstig en vertoont derhalve geen verschil.

Naast deze arbeidsmarktbrede ROA-prognoses zijn er de afgelopen tijd twee andere studies verricht die specifiek ingaan op de werkgelegenheid voor apothekersassistenten in de openbare apotheek. De eerste is de studie van De Wolf e.a. (1997), die een prognose geeft voor de totale werkgelegenheidsomvang voor apothekersassistenten in de openbare apotheek. De tweede studie is een prognosestudie van het IVA (Vermeulen e.a., 1998) die voor de hele zorgsector (onderverdeeld in sectoren) een prognose geeft van de werkgelegenheidsontwikkelingen. Beide studies geven een prognose voor een periode van ongeveer tien jaar.

De Wolf voorspelt in tegenstelling tot de in dit hoofdstuk gepresenteerde prognoses een geleidelijke afname van de werkgelegenheid voor apothekersassistenten over de periode tot 2005. Dit komt voomamelijk omdat De Wolf expliciet de (veronderstelde) effecten van toekomstige beleidswijzigingen meeneemt in zijn prognoses. Als deze effecten niet meegenomen worden, geeft ook zijn model een stijging van de werkgelegenheid te zien. Het model van De Wolf e.a. voorspelt dat het niveau van de werkgelegenheid in 2005 ongeveer 11.500 apothekersassistenten zal bedragen. Dit niveau is echter al in 1997 bereikt. Het model van De Wolf onderschat de ontwikkeling in de werkgelegenheid dus in sterke mate ${ }^{2}$. Dit komt voomamelijk omdat in dit model de groei van het aantal receptregels uitsluitend afhangt van demografisch factoren. Zoals in paragraaf 3.3 duidelijk is geworden, maken deze factoren slechts een klein deel uit van de totale groei. De te lage inschatting van De Wolf e.a. moet dus voornamelijk toegeschreven worden aan het feit dat hij de autonome trend in het medicijngebruik negeert.

In de studie van het IVA worden de apothekersassistenten in de openbare apotheek als aparte groep onderscheiden. Deze studie geeft, net als dit rapport, prognoses op basis van een stromenmodel. Het IVA baseert zich op cijfers van Cadans, en gaat dus uit van iets andere totalen dan de in dit rapport gebruikte. Het IVA gaat uit van ongeveer 9.500 werkzame apothekersassistenten in 1995, en komt tot de inschatting dat dit er in 2007 11.000 zullen zijn. Deze prognose voor de uitbreidingsvraag ligt dus veel lager dan de in dit rapport gepresenteerde. Het IVA laat de autonome trendmatige groei van het aantal recepten veel minder zwaar meewegen in de prognose. Voor de vervangingsvraag komt het IVA-model tot een vergelijkbare, zij het iets lagere, inschatting van de jaarlijkse bruto-uitstroom als het hier gehanteerde prognose-model. De jaarlijkse bruto uitstroom bedraagt volgens de IVA-prognose ongeveer 900 mensen, tegenover bijna

9. Dit is overigens een bekend verschijnsel: modellen die gebaseerd zijn op het doortrekken van waargenomen trends in de werkgelegenheidsontwikkeling hebben de neiging om de feitelijke ontwikkelingen te overschatten, modellen gebaseerd op een meer beleidsmatige aanpak van de personeelsplanning hebben de neiging de feitelijke ontwikkelingen te onderschatten (Zie ook Borghans en De Grip, 1999). 
1.200 mensen in deze studie. Het IVA rapporteert echter geen netto uitstroom, zodat een vergelijking van de prognoses voor de vervangingsvraag niet mogelijk is. 


\section{Gevoeligheidsanalyses}

\subsection{Inleiding}

In het vorige hoofdstuk is een prognose gepresenteerd van de toekomstige arbeidsmarktontwikkelingen voor apothekersassistenten in de openbare apotheek. Deze prognoses zijn gebaseerd op een aantal veronderstellingen ten aanzien van toekomstige ontwikkelingen. Zoals in de inleiding van dit rapport al is aangegeven, zijn deze ontwikkelingen op de arbeidsmarkt altijd met onzekerheden omgeven. Daarom is het voor het voeren van een preventief arbeidsmarktbeleid van belang rekening te houden met de onzekerheidsmarges in de arbeidsmarktprognoses. Om inzicht te geven in deze marges zal een aantal gevoeligheidsanalyses gepresenteerd worden, waarmee wordt aangegeven in hoeverre de prognoses afhangen van de gemaakte aannamen.

De gevolgen van diverse omgevingsfactoren op de werkgelegenheid voor apothekersassistenten zijn zeer groot. Het is dus de vraag of er betrouwbare prognoses van de werkgelegenheidsontwikkelingen voor de apothekersassistenten gemaakt kunnen worden zonder inzicht te hebben in de te verwachten ontwikkelingen in deze omgevingsfactoren. Zo onderscheidt De Wolf in zijn model een aantal factoren die het medicijngebruik (c.q. het aantal recepten) zal verminderen: de uitdunning varı het aansprakenpakket (minder aanspraken op vergoeding van medicijnen), toename van de zelfmedicatie, toename van handverkoop, directe levering (d.w.z. buiten de apotheek om) van incontinentiematerialen en griepvaccins. Deze maatregelen zijn inmiddels doorgevoerd, en hebben deels het volume van het medicijngebruik, en deets alleen de kosten van het medicijngebruik verminderd. Ook door andere maatregelen speelt de politiek een heel duidelijke rol. Er zijn pogingen gedaan om het mogelijk te maken medjcijnen te verkopen via het systeem van postorderbedrijven, de zogenaamde 'postorderfarmacie'. Een ander voorbeeld is dat het mogelijk gemaakt wordt dat de ziekenhuisapotheken ook medicijnen gaan leveren aan patiënten die niet in het ziekenhuis opgenomen zijn.

Het effect op de werkgelegenheid van dergelijke overheidsmaatregelen is zeer lastig in te schatten. Zo heeft de eigen bijdrageregeling die destijds ingevoerd is om het medicijngebruik te remmen, achteraf beschouwd weinig effect gehad. Omdat de bijdrage per recept geïnd wordt, nam weliswaar het aantal recepten af, maar niet het medicijngebruik zelf. Zo is ook het effect van de vergroting van de markt voor de ziekenhuisapotheken moeilijk in te schatten. De ziekenhuisapotheken worden verondersteld goedkoper te werken. Dit zou, bij gelijkblijvend medicijngebruik, de kosten van de gezondheidszorg verminderen. Aan de andere kant, als de medicijnen goedkoper worden, is het mogelijk dat de vraag juist toeneemt. Daardoor is het netto resultaat van dergelijk $\theta$ beleidsmaatregelen op het medicijngebruik en de werkgelegenheid voor apothekersassistenten in de openbare apotheek lastig in te schatten. 
Dit geldt des te meer omdat de nu voorgestelde maatregelen ten aanzien van de ziekenhuisapotheken niet zozeer betrekking hebben op het totale medicijngebruik, maar over de verdeling van de markt over een aantal medicijnleveranciers, namelijk de openbare apotheek en de ziekenhuisapotheek ${ }^{10}$. De marktverdeling die zal ontstaan is moeilijk te voorspellen. Ook zal er waarschijnlijk sprake zijn van een tijdelijke verhoging van de vraag naar assistenten omdat een nieuw distributiepunt een apothekersassistent nodig heeft, nog voor er sprake is van geleverde recepten. Dit zal in ieder geval tijdelijk, maar misschien ook voor langere tijd, een extra toename van de vraag tot gevolg hebben. Daamaast zal niet alleen de afzetmarkt herverdeeld worden over deze twee groepen apotheken. Ook de arbeidsmarkt wordt herverdeeld. Was tot nu toe de openbare apotheek de grootste werkgever voor de apothekersassistenten, als de omzet van de ziekenhuisapotheek toeneemt, zal ook deze als werkgever van toenemend belang zijn voor de gediplomeerde apothekersassistenten. De knelpunten die de werkgevers ondervinden bij de werving van personeel zullen dan niet alleen meer afhankelijk zijn van de schaarste of het overschot van goed opgeleide apothekersassistenten, maar ook, en misschien in nog veel sterkere mate, van de relatieve aantrekkelijkheid van het werk in de twee soorten apotheken. Ook deze effecten zijn op voorhand moeilijk te voorspellen.

Behalve het inschatten van de omvang van de effecten van de diverse maatregelen is er nog een onzekerheidscomponent. De diverse overheidsmaatregelen in het verleden waren eenmalige uitdunningen van het wettelijk aansprakenpakket. De omvang van dergelijke aanpassingen en de timing daarvan zijn in hoge mate afhankelijk van politieke besluitvorming. Het is niet mogelijk om op basis van historische gegevens in te schatten welke maatregelen genomen zullen worden, en op welke termijn. De enige conclusie die op basis van het verleden gerechtvaardigd lijkt, is dat de overheid zelden langer dan twee jaar niet ingegrepen heeft. Zeker als de kosten van de gezondheidszorg sterk stegen, heeft de overheid in het verleden ingegrepen. Het is wel zo dat het de vraag is in hoeverre de overheid in staat zal blijven om dit type volumemaatregelen te nemen. Deze mogelijkheden lijken steeds meer uitgeput te raken, zodat het accent van de kostenbesparende maatregelen steeds meer verlegd zal gaan worden naar prijsbeleid in plaats van volumebeleid. Het is dus moeilijk om het moment, de aard en de effecten van het overheidsbeleid in te schatten. Dit maakt het, zoals ook in het vorige hoofdstuk al is gezegd, noodzakelijk om na te gaan in welke mate de prognoses afhangen van afwijkingen van de veronderstelde groei.

De beste strategie om een indruk te krijgen van de gevoeligheid van de prognoses voor diverse aannamen is om aan te geven welke afwijkingen ten opzichte van het basisscenario denkbaar zijn, en wat daarvan de gevolgen zijn voor de diverse vraag- en aanbodcomponenten, en de daaruit resulterende knelpunten op de arbeidsmarkt. In dit

10. In principe hoort hier ook de 'postorderapotheek' nog bij, maar na een aantal pogingen deze van de grond te krijgen bestaat deze momenteel niet meer. 
hoofdstuk zal de gevoeligheid voor een paar van de belangrijkste determinanten getoond worden. Het gaat dan om de bevolkingsgroei, de lengte van de gemiddelde werkweek, de autonome trend in het aantal recepten, veranderingen in de uitstroomkans en tot slot een verandering in het aantal schoolverlaters van de opleiding tot apothekersassistent. Bedacht moet worden dat alle analyses partieel zijn, dat wil zeggen dat er geen rekening gehouden wordt met het feit dat sommige afwijkingen van het basisscenario tegelijkertijd op kunnen treden. Een eerste indicatie voor de effecten die optreden als er meerdere afwijkingen tegelijkertijd optreden zou verkregen kunnen worden door de respectievelijk verwachte veranderingen in de tekorten bij elkaar op te tellen.

\subsection{Veranderingen in de uitbreidingsvraag}

In deze paragraaf zal worden ingegaan op de vraag in hoeverre de werkgelegenheid voor de apothekersassistenten wijzigt als een aantal ontwikkelingen anders verlopen dan in het basisscenario is aangenomen. Hierbij wordt ook aangegeven in hoeverre er veranderingen optreden in de tekorten. Achtereenvolgens zal worden aangegeven wat de effecten zijn van een veel lagere of hogere bevolkingsgroei. Ook wordt aangegeven in hoeverre de knelpunten op de arbeidsmarkt veranderen als gevolg van veranderingen in de lengte van de gemiddelde werkweek van apothekersassistenten. Omdat het beleid van de overheid er op gericht lijkt te zijn het medicijngebruik per hoofd van de bevolking te beïnvloeden, zal dit beleid voornamelijk invloed hebben op de 'autonome trend' in het medicijngebruik die in de prognoses is opgenomen. Zoals uit het vorige hoofdstuk al bleek, is deze autonome trend een zeer bepalende factor voor de verwachte tekorten.

\section{Bevolkingsgroei}

Omdat het totale medicijngebruik in Nederland afhangt van de omvang van de bevolking, is het de vraag in hoeverre de verwachte tekorten veranderen als de bevolkingsgroei lager of juist hoger is dan momenteel wordt verwacht. Hierbij zal worden gekeken naar de gevolgen van de lage en hoge bevolkingsgroeivariant van het CBS. In de lage variant groeit de bevolking naar 15,8 miljoen mensen in 2007, in de hoge variant is dit 16,8 miljoen. Bij beide varianten wordt uitgegaan van dezelfde vergrijzingsgraad als in het basisscenario. In principe valt het te verwachten dat de vergrijzing sterker wordt naarmate de bevolkingsgroei afneemt, maar het CBS geeft geen prognoses voor de vergrijzingsgraad bij de lage en de hoge groeivariant. Ook wordt aangenomen dat de verschillen in bevolkingsgroei de eerstkomende jaren geen effect zullen hebben op de aantallen schoolverlaters.

In tabel 4.1 is te zien wat de effecten zijn van deze andere aannamen ten aanzien van de bevolkingsgroei. De groei van het aantal receptregels ligt bij een lage bovolkingsgroei op 3,7\% per jaar, iets lager dan in het basisscenario waarin een groei van $3,9 \%$ wordt verwacht. Als gevolg daarvan loopt de uitbreidingsvraag tot 2006 bij een lage 
groei terug tot 4.300 assistenten, bijna 400 minder dan in het basisscenario. Omdat de omvang van de werkgelegenheid lager is, is ook de vervangingsvraag geringer, al is het relatieve verschil ten opzichte van het basisscenario veel kleiner dan voor de uitbreidingsvraag. Omdat het verwachte aanbod aan schoolverfaters gelijk is gebleven is het verwachte tekort over de gehele periode lager, namelijk 5.130 in plaats van 5.620 gediplomeerde apothekersassistenten. Duidelijk mag zijn dat ook bij een lage bevolkingsgroei de tekorten aanzienlijk blijven. Voor de hoge bevolkingsgroei geldt precies het tegenovergestelde: in dat geval ligt de groei van het aantal receptregels op $4,1 \%$ per jaar, en ligt dus ook de uitbreidingsvraag hoger dan in het basisscenario. Omdat de totale groep werkenden groter is, is ook de vervangingsvraag wat groter. Dit samen leidt tot een hoger aantal baanopeningen. Het verwachte tekort zal dus bij een hoge bevolkingsgroei hoger liggen dan in het basisscenario. In dat geval zou tweederde van de stille reserve die op 1 januari 1997 aanwezig was ingezet moeten worden om de tekorten het hoofd te bieden. Het lijkt ondoenlijk om zo'n grote groep te 'reactiveren'.

Tabel 4.1

De arbeidsmarktsituatie bij verschillende ontwikkelingen in de bevolkingsgroei, 1998 - 2006

\begin{tabular}{llllll}
\hline & $\begin{array}{l}\text { Uitbreidings- } \\
\text { vraag }\end{array}$ & $\begin{array}{l}\text { Vervangings- } \\
\text { vraag }\end{array}$ & $\begin{array}{l}\text { Baan- } \\
\text { openingen }\end{array}$ & $\begin{array}{l}\text { Aanbod } \\
\text { schoolver- } \\
\text { laters }\end{array}$ & Tekort \\
\hline Basisscenario (matige groei) & 4.690 & 5.700 & 10.390 & 4.770 & 5.620 \\
Lage groei bevolking & 4.300 & 5.600 & 9.900 & 4.770 & 5.130 \\
Hoge groei bevolking & 5.070 & 5.780 & 10.850 & 4.770 & 6.080 \\
\hline
\end{tabular}

Bron: ROA

Lengte van de gemiddelde werkweek

Een tweede factor die van belang is voor de werkgelegenheid van apothekersassistenten is de lengte van de gemiddelde werkweek. De afgelopen jaren is deze werkweek steeds korter geworden, niet in de laatste plaats door de algehele arbeidstijdverkorting van 38 naar 36 uur per week. Daamaast is ook het percentage deeltijders gegroeid. Tabel 4.2 geeft een beeld van de effecten van een (geleidelijke) verandering van de lengte van de gemiddelde werkweek op de verwachte arbeidsmarktsituatie voor apothekersassistenten. Bij de berekeningen in deze tabel is er van uitgegaan dat veranderingen in de gemiddelde werkweek zich volledig vertalen in het aantal assistenten, zonder dat de productiviteit per assistent verandert ${ }^{11}$. In de tabel is aangegeven wat de tekorten zullen zijn bij respectievelijk een afname van de gemiddelde werkweek

11. De veronderstelling van volledige herbezetting is mogelijk niet geheel juist, omdat in een relatief kleine apotheek bij een arbeidsduurverkorting waarschijnlijk geen herbezetting plaats zal vinden. Bij een gelijkblijvend aantal recepten zal in dat geval de productiviteit van de apothekersassistenten toenemen. Deze toename komt dan bovenop de toename die al in het basisscenario is verondersteld. 
tot 25 uur per week, een afname tot 27 uur per week en een toename tot 29 uur per week. Deze laatste wijziging ten opzichte van het basisscenario is toegevoegd omdat er als gevolg van de verwachte tekorten aan personeel mogelijk een tendens zal ontstaan om de deeltijdwerkenden die daartoe bereid zijn voor meer uren per week in dienst te nemen.

In de tabel is te zien dat een verdere afname van de werkweek tot 25 uur per week zal leiden tot een enorme uitbreidingsvraag wanneer de vrijgekomen uren opnieuw bezet moeten worden. De uitbreidingsvraag bedraagt dan ongeveer 6.400 personen, een toename ten opzichte van het basisscenario van ruim 1.700 personen. Omdat de uitstroom gerelateerd is aan het aantal werkenden, zal als gevolg van het toegenomen aantal assistenten ook de vervangingsvraag toenemen. Hierdoor neemt het aantal baanopeningen ten opzichte van het basisscenario met ongeveer 2.100 mensen toe. Bij een gelijkblijvend aantal schoolverlaters neemt ook het tekort met ongeveer 2.100 mensen toe. Bij gebrek aan voldoende schoolveriaters zal dit tekort gevuld moeten worden met herintreders en werklozen die een baan in de openbare apotheek zoeken. In dat geval zal maar liefst $80 \%$ van de totale stille reserve moeten herintreden. Het zal onmogelijk zijn dit te realiseren. Aan de andere kant moet bedacht worden dat het mogelijk maken van werken in deeltijd de drempel naar de arbeidsmarkt voor een deel van deze stille reserve wel lager kan maken. Als de verkorting van de gemiddelde werkweek dus niet veroorzaakt wordt doordat nu werkenden minder gaan werken, maar dat er een extra instroom van deeltijdwerkers in de apotheek plaatsvindt, kan dit een deel van de oplossing voor de verwachte tekorten vormen. Bij een afname van de gemiddelde werkweek tot 27 uur per week zal het tekort iets hoger uitvallen dan verwacht wordt bij een afname tot 27,5 uur per week, waarvan is uitgegaan voor het basisscenario.

Als gekeken wordt wat de effecten zijn van een verlenging van de gemiddelde werkweek blijkt ook weer dat een aanpassing van de omvang van de werkweek grote effecten heeft. In het geval van een verlenging van de gemiddelde werkweek met ruim een uur zal het verwachte tekort van 5.620 assistenten met ongeveer $20 \%$ verminderen tot ruim 4.480 mensen. Dit geeft aan dat de omvang van de tekorten in principe door vrij kleine aanpassingen in de gemiddelde werkweek opgevangen zouden kunnen worden. Het zogenaamde 'op-plussen' van bestaande deeltijdcontracten is derhalve voor werkgevers een aantrekkelijke optie om de knelpunten in de personeelsvoorziening te verminderen. 
De arbeidsmarktsituatie bij verschillende ontwikkelingen van de lengte van de werkweek, $1998-2006$

$\begin{array}{llll}\begin{array}{l}\text { Uitbreidings- } \\ \text { vraag }\end{array} & \begin{array}{l}\text { Vervangings- } \\ \text { vraag }\end{array} & \begin{array}{l}\text { Baan- } \\ \text { openingen }\end{array} & \begin{array}{l}\text { Aanbod } \\ \text { schoolver- } \\ \text { laters }\end{array}\end{array}$

\section{Basisscenario}

(27,5 uur per week)

25 uur per week in 2006

27 uur per week in 2006

29 uur per week in 2006
4.690

3.380

2.270

1.312
5.700

5.330

5.070

4.810
10.390

8.710

7.330

6.120
4.770

5.620

Bron: ROA

In het basisscenario voor de uitbreidingsvraag is uitgegaan van een autonome trend in het medicijngebruik van $3,5 \%$ op jaarbasis. Samen met het effect van de bevolkingsgroei en de vergrijzing op de groei van het medicijngebruik levert dit een totale groei van het aantal recepten op van circa $4 \%$ per jaar. Diverse ontwikkelingen kunnen ertoe leiden dat deze autonome trend sterker wordt, of juist wordt omgebogen tot zelfs een gelijk blijven of afnemen van het medicijngebruik per hoofd van de bevolking. Groot (1998) constateert dat we bij toenemende welvaart steeds grotere bedragen over hebben voor onze gezondheid. Omdat de welvaart de komende jaren zal blijven toenemen, valt te verwachten dat we dus ook steeds meer gaan besteden aan onze gezondheid. Dit zou betekenen dat de autonome trend in het medicijngebruik de komende jaren zeker niet kleiner zal worden. Aan de andere kant, juist omdat de gezondheidszorg een steeds groter beslag legt op de beschikbare middelen, wordt door de overheid getracht deze trend af te zwakken of zelfs om te buigen. Het laatste argument is echter veel meer een financieel argument: als de omvang van het medicijngebruik toeneemt bij gelijkblijvende kosten, zal de overheid waarschijnlijk veel minder geneigd zijn het medicijngebruik af te remmen. Voor de werkgelegenheid in de openbare apotheken is echter de omvang van de zorg van veel groter belang dan de kosten van de zorg. Daarom is er in het basisscenario van uitgegaan dat de omvang van het medicijngebruik zal blijven stijgen.

Als het marktaandeel van de ziekenhuisapotheken toeneemt, zal de vraag naar medicijnen via de apotheek afnemen, hetgeen ook zal resulteren in een afname van de autonome trend. Niet voor het medicijngebruik per inwoner, maar wel voor het aantal recepten dat via de openbare apotheek afgeleverd wordt. Waarschijnlijk zal er in dat ge- 
val zelfs sprake zijn van een forse afname van het totaal aantal recepten dat via de openbare apotheek afgeleverd zal gaan worden ${ }^{12}$.

In tabel 4.3 is aangegeven wat de ontwikkelingen en de verwachte tekorten zijn voor verschillende ontwikkelingen van de autonome groei in het medicijngebruik. Zoals in paragraaf 3.3 is aangegeven is de autonome groei van het medicijngebruik dat gedeelte van de structurele groei dat niet wordt veroorzaakt door demografische ontwikkelingen. Omdat de feitelijke groei, als gevolg van overheidsmaatregelen in het verleden lager lag dan de structurele groei, is bij deze gevoeligheidsanalyses gekozen voor waarden voor de autonome groei die lager liggen dan de structurele groei waar het basisscenario op gebaseerd is ${ }^{13}$. Een lagere groei van het aantal recepten is bijvoorbeeld te verwachten als de ziekerihuisapotheken een groot marktaandeel zullen verwerven ten opzichte van de openbare apotheken. De verwachte groei van het medicijngebruik ligt als gevolg van demografische ontwikkelingen ongeveer een halve \%punt hoger dan de autonome trend ${ }^{14}$. De verwachte tekorten zijn getoond voor een situatie waarin de autonome groei afwezig is, en een autonome groei van resp. twee en vier \% op jaarbasis.

Als er geen sprake is van een autonome toe- of afname van het medicijngebruik hangt de stijging van het medicijngebruik uitsluitend af van de demografische ontwikkelingen. Tabel 4.3 laat zien dat in dat geval vraag en aanbod van apothekersassistenten elkaar ongeveer in evenwicht zullen houden. Er zal dan over 9 jaar een tekort ontstaan van ongeveer 600 assistenten. Vanwege dit kleine tekort wordt verondersteld dat de productiviteit van de apothekersassistenten gelijk blijft op het niveau van 1996. Ook is er bij de berekening van dit tekort afgezien van veranderingen in het aantal schoolverlaters dat werk zoekt in de openbare apotheek. Deze veronderstelling is zeker niet juist als bijvoorbeeld een stijging van het marktaandeel van de ziekenhuisapotheken de oorzaak is van de afname. In dat geval zal waarschijnlijk ook het aantal schoolveriaters dat een baan zoekt in de openbare apotheek afnemen.

Zodra er sprake is van een autonome toename van het medicijngebruik, zullen er tekorten ontstaan. Zoals aangegeven wordt in tabel 4.3 hebben deze tekorten een relatief grote omvang. Bij een autonome groei van $2 \%$ - een totale groei van ongeveer $2,5 \%$ - hebben de tekorten een omvang van in totaal 2.610 , bijna eenderde van de omvang van de totale stille reserve. Bij een autonome groei van $4 \%$ op jaarbasis heeft het tekort een omvang van maar liefst ruim tweederde van de ornvang van de stille reserve. De

12. De Wolf veronderstelt als gevolg van de diverse maatregelen - zoals de uitdunning van het aansprakenpakket, de introductie van de postorderfarmacie - een afname van het aantal recepten met $8 \%$ tot 2005 .

13. In de terminologie van hoofdstuk 3, wordt hier dus in feite de 'incidentele groef' als gevolg van het overheidsbeleid verrekend met de autonome groei.

14. In 1998 ligt de verwachte groei een volle procentpunt hoger dan de autonome groei, in 2006 - als gevolg van een afnemende bevolkingsgroei - nog slechts een kwart procentpunt hoger. 
omvang van het tekort heeft dan een onoplosbare omvang. Dat wil zeggen, in dat geval is het deel van de stille reserve dat ingezet moet worden zo groot, dat dit waarschijnlijk niet haalbaar is. Een dergelijke groei over een langere periode kan de sector dus niet aan zonder dat er grote aanpassingen plaats zullen vinden. Gedacht moet dan worden aan een verdere productiviteitsverhoging, verlenging van de gemiddelde werkweek, en waarschijnlijk ook aanpassingen in de primaire of secundaire arbeidsvoorwaarden om het beroep aantrekkelijker te maken.

Tabel 4.3

De arbeidsmarktsituatie bij verschillende ontwikkelingen in de autonome groei van het medicijngebruik, $1998-2006^{\text {a) }}$

$\begin{array}{lllll}\text { Medicijngebruik } & \begin{array}{l}\text { Uitbreidings- } \\ \text { vraag }\end{array} & \begin{array}{l}\text { Vervangings- Baan- } \\ \text { vraag } \\ \text { openingen }\end{array} & \begin{array}{l}\text { Aanbod } \\ \text { schoolver- } \\ \text { laters }\end{array}\end{array}$

\begin{tabular}{|c|c|c|c|c|c|}
\hline $\begin{array}{l}\text { Basisscenario } \\
\text { (3.5\% autonome groei) }\end{array}$ & 4.690 & 5.700 & 10.390 & 4.770 & 5.620 \\
\hline $\begin{array}{l}0 \% \text { autonome groel } \\
2 \% \text { autonome groel } \\
4 \% \text { autonome groel }\end{array}$ & $\begin{array}{r}704 \\
2.300 \\
5.590\end{array}$ & $\begin{array}{l}4.650 \\
5.070 \\
5.900\end{array}$ & $\begin{array}{r}5.360 \\
7.380 \\
11.490\end{array}$ & $\begin{array}{l}4.770 \\
4.770 \\
4.770\end{array}$ & $\begin{array}{r}590 \\
2.610 \\
6.720\end{array}$ \\
\hline
\end{tabular}

\subsection{Veranderingen In de vervangingsvraag}

Ook de vervangingsvraag is afhankelijk van een aantal ontwikkelingen zoals de aantrekkelijkheid van het beroep, de mogelijkheden om arbeid en zorg te combineren en de arbeidsmarktmogelijkheden buiten de apotheek. Een deel van de vervangingsvraag is niet door de werkgever te beïnvloeden omdat de pensioenleeftijd vast ligt. Daamaast wordt echter een zeer groot deel van de uitstroom van personeel veroorzaakt doordat werknemers, na een aantal jaren in de apotheek gewerkt te hebben, zich terugtrekken van de arbeldsmarkt vanwege b.v. de verzorging van de eigen kinderen. Deze uitstroom is door de apotheken misschien wel te beïnvloeden. Als het moeilijk is om werk en gezin te combineren zullen de (merendeels vrouwelijke) werknemers sneller kiezen om te stoppen met werken. Hoe beter de faciliteiten zijn om werk en gezin te kunnen combineren, hoe langer de werknemers zullen blijven werken. Dit geldt ook voor de mogeijjkheden om binnen de apotheek carrière te maken, of om in de loop van de tijd meer inhoud aan de functie te geven. Te denken valt hierbij aan een uitbreiding van de taken en verantwoordelijkheden, gecombineerd met een salarisstijging. Ook in dat geval zal men de neiging hebben om langer te blijven werken, en waarschijnlijk ook meer te investeren in bijvoorbeeld bijscholing.

Als daarentegen de situatie ontstaat dat de werkgevers zich niet inspannen om personeel langer in de apotheek te houden, zouden werknemers de indruk kunnen krijgen 
'ongewenst te worden'. Als gevolg daarvan zal men gaan zoeken naar werkgelegenheid buiten de apotheek, al dan niet in het beroep van apothekersassistent. Deze situatie zou kunnen ontstaan als er sprake is van flinke overschotten aan apothekersassistenten. In dat geval zou de apotheek de suggestie kunnen wekken de voorkeur te geven aan relatief goedkope schoolverlaters in plaats van aan oudere, meer ervaren, werknemers. Als dit zo is, zullen de ouderen ofwel sneller stoppen met werken, ofwel op zoek gaan naar werk in een andere sector.

In tabel 4.4 wordt aangegeven in hoeverre de tekorten veranderen als de uitstroom ten opzichte van het basisscenario met $5 \%$ afneemt, en wat er gebeurt als de uitstroom met $5 \%$ toeneemt. Omdat de relatie tussen de uitstroom en de vervangingsvraag niet lineair is vanwege de mobiliteit binnen de apothekersbranche, is de verandering in de vervangingsvraag niet exact $5 \%$. Uit de tabel blijkt dat als de komende jaren de uitstroom 5\% lager ligt, het tekort 300 mensen lager zal liggen dan in het basisscenario. Beperking van de uitstroom kan dus bijdragen aan de oplossing van de verwachte tekorten, maar kan zeker niet de enige oplossing zijn. Om het hele tekort via beperking van de uitstroom weg te werken, zal de personeelsuitstroom in feite geheel gestopt moeten worden.

Tabel 4.4

De arbeidsmarktsituatie bij verschillende ontwikkelingen in de uitstroomkans, 1998 - 2006

$\begin{array}{llll}\begin{array}{l}\text { Uitbreidings- } \\ \text { vraag }\end{array} & \begin{array}{l}\text { Vervangings- } \\ \text { vraag }\end{array} & \begin{array}{l}\text { Baan- } \\ \text { openingen }\end{array} & \begin{array}{l}\text { Aanbod } \\ \text { schoolver- } \\ \text { laters }\end{array}\end{array} \quad \begin{aligned} & \text { Tekort } \\ & \end{aligned}$

\begin{tabular}{llllll}
\hline Basisscenario & 4.690 & 5.700 & 10.390 & 4.770 & 5.620 \\
$5 \%$ daling & 4.690 & 5.400 & 10.090 & 4.770 & 5.320 \\
$5 \%$ groei & 4.690 & 6.010 & 10.700 & 4.770 & 5.930 \\
\hline
\end{tabular}

Bron: ROA

Er moet bij de resultaten in deze tabel wel bedacht worden dat er geen rekening is gehouden met een eventuele samenhang tussen de stromen, of van een gezamenlijke oorzaak die verschillende stromen tegelijkertijd beïnvloedt. Wanneer bijvoorbeeld de arbeidsvoorwaarden in de apotheek slechter zijn dan in de industrie, dan zal waarschijnlijk de uitstroom van apothekersassistenten die de overstap naar de industrie maken, toenemen. Tegelijkertjjd zal ook het aantal schoolverlaters dat werk zoekt in de openbare apotheek afnemen. In dat geval zal het tekort veel groter zijn dan in de tabel gesuggereerd wordt. Het omgekeerde geldt uiteraard ook: als het beroep van apothekersassistent een zeer goed salaris biedt in vergelijking met andere beroepen op dat niveau, dan zal de uitstroom waarschijnlijk afnemen. Tegelijkertijd zal de opleiding waarschijnlijk populairder worden dan zij nu is. in dat geval loopt het tekort veel sneller terug dan de tabel op basis van een partiële analyse aangeeft. 


\subsection{Veranderingen In de instroom van schoolverlaters}

Als laatste in dit hoofdstuk zal de gevoeligheid van de prognoses voor de verandering in het aantal schoolverlaters worden belicht. Het aantal schoolverlaters wordt door verschillende factoren beïnvloed. Allereerst is de groei van de bevolking bepalend voor de aantallen schoolverlaters. Deze bevolkingsgroei is verwerkt in de Referentieramingen van het ministerie. De prognose van het aantal schoolverlaters is gebaseerd op het verwachte aantal schoolverfaters in de richting (M)DGO/MBO assistenten gezondheidszorg. Binnen deze richting vallen naast de apothekersassistenten ook de dokters- en tandartsassistenten. In het basisscenario is er van uitgegaan dat de onderlinge verhouding tussen deze drie richtingen de komende jaren niet zal wijzigen. Als gevolg van uiteenlopende ontwikkelingen in de werkgelegenheid en de relatieve aantrekkelijkheid van de drie beroepen, is het echter mogelijk dat deze verhouding wel verandert. Als er sprake is van toenemende tekorten op de markt voor apothekersassistenten zal het aantal scholieren dat kiest voor de opleiding tot apothekersassistent waarschijnlijk toenemen. Bij een overschotsituatie zal het omgekeerde proces optreden, waardoor het aantal afstuderende apothekersassistenten afneemt. Het hangt van de reactiesnellheid en reactiesterkte af of er sprake zal zijn van een varkenscyclus: een varkenscyclus treedt alleen op als de toe- of afname van het aantal schoolverlaters groter is dan de verandering die nodig is om tekorten of overschotten te voorkomen. Dus als de afname van het aanbod van gediplomeerde schoolverlaters groter is dan de vraagafname, zal een tekort automatisch omslaan in een overschot en vice-versa. Als de aanpassing vrij snel verloopt, en kleiner is dan de vraagverandering, zal een proces ontstaan waarin de vraag en aanbod naar een evenwicht tenderen. Het is dus voor de apotheken, zeker als het fenomeen van een varkenscyclus optreedt, van belang om in een vrij vroeg stadium een inschatting te maken van de toekomstige vraag naar apothekersassistenten en te zoeken naar andere wegen om aan personeel te komen, als hel verwachte aanbod van schoolverlaters te klein is. Dit voorkomt dat de discrepanties tussen vraag en aanbod een al te grote omvang aan zullen nemen.

In tabel 4.5 is te zien in hoeverre het in het basisscenario verwachte tekort aan apothekersassistenten toe- of afneemt als het aantal schoolverlaters afwijkt ten opzichte van het basisscenario. Deze veranderingen kunnen, zoais gezegd, verschillende oorzaken hebben: het totaal aantal schoolverlaters van de opleiding tot apothekersassistent kan veranderen, of het percentage van hen dat kiest voor een baan als apothekersassistent in de openbare apotheek kan veranderen. Tot slot kan een tekort ook sterk beïnvloed worden door de relatieve aantrekkelijkheid van een bepaald soort baan. Deze relatieve aantrekkelijkheid wordt bepaald door zaken als (relatieve) beloning, carrièremogelijkheden en mogelijkheden tot persoonlijke ontplooiing binnen de werksituatie. Ook secundaire arbeidsvoorwaarden, mogelijkheden voor kinderopvang en arbeidsomstandigheden hebben vaak een belangrijke invloed op het imago van een beroep en de daarop gerichte opleiding. Tabel 4.5 laat zien dat als het aantal schoolverlaters afneemt met 
$10 \%$ het tekort oploopt met bijna 500 mensen tot ruim 6.100. Deze toename van het tekort is iets groter dan de afname in het aantal schoolverlaters. Dit is een gevolg van het feit dat er in plaats van schoolveriaters herintreders geworven moeten worden. Deze herintreders zijn gemiddeld genomen wat ouder. Dit leidt tot een iets hogere mobiliteit, en dus een hogere vervangingsvraag dan in het basisscenario. Het omgekeerde doet zich voor bij een toename van het aantal schoolverlaters met $10 \%$. Hierdoor neemt het tekort af met circa 500 mensen tot 5.130 mensen over de hele periode tot 2006. Dit heeft tot gevolg dat er minder mensen uit de stille reserve geworven hoeven te worden. Hierdoor neemt de vervangingsvraag ook iets af ten opzichte van het basisscenario. Daardoor is de afname van het tekort iets groter dan de toename van het aantal schoolverlaters.

Ook hier geldt weer dat een toename van het aantal schoolverlaters, of een stijging van het deel van hen dat kiest voor een baan in de openbare apotheek, kan bijdragen aan de beperking van de verwachte tekorten. Gezien echter de verwachte omvang van de tekorten in het basisscenario, zal een toename van het aantal schoolverlaters nooit de enige oplossing kunnen zijn.

\section{Tabel 4.5}

De arbeidsmarktsituatie bij verschillende ontwikkelingen in het aanbod van schoolverlaters, 1998 - 2006

\begin{tabular}{llllll}
\hline & $\begin{array}{l}\text { Uitbreidings- } \\
\text { vraag }\end{array}$ & $\begin{array}{l}\text { Vervangings- Baan- } \\
\text { vraag }\end{array}$ & $\begin{array}{l}\text { Aanbod } \\
\text { openingen } \\
\text { schoolver- } \\
\text { laters }\end{array}$ & Tekort \\
\hline Basisscenario & 4.690 & 5.700 & 10.390 & 4.770 & 5.620 \\
$10 \%$ daling & 4.690 & 5.710 & 10.400 & 4.290 & 6.110 \\
$5 \%$ daling & 4.690 & 5.710 & 10.400 & 4.530 & 5.870 \\
$5 \%$ groei & 4.690 & 5.690 & 10.380 & 5.010 & 5.370 \\
$10 \%$ groei & 4.690 & 5.680 & 10.370 & 5.250 & 5.130 \\
\hline
\end{tabular}

Bron: ROA 


\section{Conclusies en aanbevelingen}

\subsection{Conclusies}

De situatie op de arbeidsmarkt voor apothekersassistenten is in het verleden onderhevig geweest aan grote fluctuaties. Er zijn perioden geweest van tekorten, en perioden van (zij het kleine) overschotten. Omdat de markt voor apothekersassistenten een vakdeelmarkt is, is het moeilijk om op korte termijn grotere tekorten op te lossen. Vandaar dat een preventief arbeidsmarktbeleid vereist is, om te voorkomen dat men geconfronteerd wordt met grote onevenwichtigheden. Een dergelijk beleid vereist echter wel inzicht in de aard en omvang van de verwachte problemen. Dit rapport geeft prognoses voor vraag en aanbod van apothekersassistenten in de openbare apotheek voor de komende jaren. Deze prognoses kunnen dienen als basis voor het te voeren beleid. In tegenstelling tot eerder onderzoek is in dit rapport zeer specifiek gekeken naar personeel met een opleiding tot apothekersassistent dat werkzaam is in de openbare apotheek.

Zoals reeds eerder is aangegeven zijn de aard en de omvang van de overheidsmaatregelen in de zorgsector de meest bepalende factoren voor de arbeidsmarktsituatie. Dit is een complicerende factor voor het maken van prognoses. Dit overheidsbeleid ten aanzien van de zorg is namelijk in hoge mate afhankelijk van politieke besluitvorming, en in die zin moeilijk voorspelbaar. Voor het in dit rapport uitgewerkte basisscenario is er uitgegaan van een 'beleidsarme' ontwikkeling. Dit betekent dat de structurele groei van het aantal receptregels als uitgangspunt is genomen. Deze structurele groei is berekend als de gemiddelde groei van het medicijngebruik per hoofd van de bevolking over de afgelopen jaren wanneer er geen overheidsmaatregelen genomen zouden zijn. Deze structurele groei valt voor een deel toe te wijzen aan demografische factoren, en voor een deel aan een autonome stijging van het medicijngebruik per hoofd van de bevolking, waarbij deze laatste component de meest bepalende blijkt te zijn.

Voor het basisscenario zijn er enkele aannamen gemaakt. Ten eerste ten aanzien van de bevolkingsgroei en de vergrijzing. Hiervoor zijn de prognoses van het $C B S$ gehanteerd. Daamaast is verondersteld dat er in de komende jaren nog een lichte afname van de lengte van de gemiddelde werkweek op zal treden, maar dat als gevolg van tekorten de productiviteit van de apothekersassistenten weer licht op zal lopen. De verwachte uitstroom van nu werkenden is gebaseerd op waargenomen uitstroompatronen in de afgelopen jaren. Hievan wordt verondersteld dat zij niet zullen wijzigen. De instroom van schoolverlaters is gebaseerd op de prognoses van het Ministerie van Onderwijs, Cultuur en Wetenschappen. Omdat niet alle afgestudeerden van de opleiding tot apothekersassistent ook daadwerkelijk in de openbare apotheek gaat werken, is er op basis van gegevens van het ROA een fractie bepaald van het aantal schoolverlaters dat wel in de openbare apotheek gaat werken. Ook deze fractie wordt constant verondersteld. 
Uitgaande van deze aannamen blijkt dat er voor de jaren tot 2006 een groot tekort aan apothekersassistenten op zal gaan treden. Volgens het basisscenario zal de komende jaren sprake zijn van een groei van de werkgelegenheid van ongeveer $4 \%$ op jaarbasis. Dit betekent een groei van de werkgelegenheid (de uitbreidingsvraag) in de periode 1998 - 2006 van ruim 4.690 personen. Daamaast zijn er om de vertrekkende assistenten te vervangen ongeveer 5.700 mensen nodig (de vervangingsvraag). Deze vervangingsvraag neemt de komende jaren overigens af omdat de apothekersassistenten steeds langer blijven werken. De nieuwe banen als gevolg van de groei van de werkgelegenheid en de opengevallen plaatsen vanwege het vertrek van personeel vormen tezamen de baanopeningen voor de nieuwkomers op de arbeidsmarkt. Deze baanopeningen zijn de plekken waar schoolverlaters en herintreders kunnen gaan werken. Naar verwachting zullen tot het jaar 2006 ongeveer 6.800 schoolverlaters op de arbeidsmarkt instromen. Van hen zal naar verwachting ongeveer $70 \%$ een baan zoeken in de openbare apotheek. Dat betekent dus dat het totale aanbod van schoolverlaters van de opleiding tot apothekersassistent voor de openbare apotheek ongeveer 4.800 bedraagt. Dit aanbod van schoolverlaters is aanzienlijk kleiner dan het totale aantal baanopeningen van ruim 10.000 , waardoor er sprake is van een verwacht tekort van ruim 5.600 apothekersassistenten. Dit tekort kan uit drie bronnen opgevuld worden. Allereerst kan door een groter deel van de schoolverlaters over te halen te kiezen voor een baan in de openbare apotheek een bijdrage worden geleverd aan het verminderen van toekomstige tekorten. In de prognoses wordt er namelijk van uitgegaan dat $30 \%$ van de schoolverlaters elders een baan vindt. Dit betreft tot 2006 ongeveer 950 schoolverlaters. Ten tweede waren er op 1 januari 1997 nog ongeveer 900 werklozen met een MBO-opleiding tot apothekersassistent. Deze groep wordt echter snel kleiner, op 1 januari 1998 waren er nog 735 werklozen. Ten derde kan het tekort ook opgevuld worden wanneer een deel van de 'stille reserve' weer op zoek gaat naar een baan in een openbare apotheek. Deze stille reserve wordt gevormd door bijna 9.000 mensen die ooit tot apothekersassistent opgeleid zijn, maar zich nu niet (meer) op de arbeidsmarkt bevinden. Er zullen dus maatregelen genomen moeten worden om deze stille reserve actief te benaderen en te reactiveren. Hierbij kan misschien gedacht worden aan eenzelfde actie die onlangs door het Ministerie van Onderwijs, Cultuur en Wetenschappen gehouden is onder de niet-participerenden met een onderwijsbevoegdheid. Ook die sector heeft te maken met onvervulbare tekorten. ledereen die ooit in het onderwijs heeft gewerkt, maar daar thans niet meer werkzaam is, is benaderd met de vraag of hij of zij opnieuw een baan in het onderwijs wil overwegen. Ook de apothekersassistenten zouden op die manier benaderd kunnen worden.

Op basis van de veranderingen in het arbeidsmarktgedrag van werknemers dat in de afgelopen jaren waargenomen is, zijn veranderingen in de opbouw van het personeelsbestand te verwachten. Momenteel is de gemiddelde leeftijd van apothekersassistenten ongeveer 34 jaar; in 2006 zal dat toegenomen zijn tot bijna 37 jaar. Datzelfde geldt voor de lengte van het dienstverband. Op basis van de nu waargenomen uitstroom gerelateerd aan de lengte van het dienstverband is te verwachten dat ook de gemiddelde 
lengte van het dienstverband zal toenemen: van momenteel bijna zes jaar tot ongeveer acht jaar in het jaar 2006.

Voor een adequaat preventief arbeidsmarktbeleid is het van groot belang dat er in de toekomst een veel duidelijkere afstemming plaatsvindt tussen het gevoerde zorgbeleid en het arbeidsmarktbeleid voor de zorgsector, zodat al bij de ontwikkeling van het beleid de consequenties voor de arbeidsmarkt betrokken zullen worden.

In hoofdstuk 4 is een aantal partiële analyses uitgevoerd om aan te geven in hoeverre de prognoses afhangen van de aannamen over de groei van de werkgelegenheid, de aantallen schoolverlaters, etc. Aanpassingen van de lengte van de gemiddelde werkweek kunnen bijdragen om de tekorten te verminderen, maar er zullen zeer grote veranderingen nodig zijn om de tekorten op deze wijze op te lossen. De gemiddelde werkweek zal toe moeten nemen tot meer dan 30 uur per week om de tekorten op te lossen. Wel is het natuurlijk zo dat het aanbieden van kleine deeltijd contracten voor sommige niet-participerenden de drempel om weer te gaan werken lager kan maken.

De groei in het medicijnverbruik heeft daarentegen bijzonder grote effecten op de verwachte tekorten. In het basisscenario is uitgegaan van een structurele groei, zonder overheidsingrijpen. Deze structurele groei wordt veroorzaakt door demografische factoren en een autonome groei van het medicijnverbruik per hoofd van de bevolking. Variaties in de bevolkingsgroei leiden slechts tot kleine veranderingen in de verwachte tekorten. Veranderingen in de autonome groei hebben daarentegen wel een groot effect op de verwachte tekorten. Toch zal de autonome groei tot nul gereduceerd moeten worden om de tekorten te voorkomen. Deze autonome groei ligt echter buiten de invloedssfeer van de apotheken, maar wordt bepaald door de vraag van de consument naar medicijnen. Deze vraag wordt voor een deel bepaald door het door de overheid gevoerde beleid. Omdat de vraag de afgelopen jaren dermate gestegen is dat de kosten van de gezondheidszorg te hoog werden, heeft de overheid in het verleden een aantal malen ingegrepen in een poging de kosten te beheersen. Voor een deel kurınen de kosten door prijsmaatregelen beperkt worden, voor een ander deel heeft men in het verleden volumemaatregelen getroffen. De mate waarin deze maatregelen effect hebben op de groei van de vraag naar medicijnen laat zich echter moeilijk voorspellen.

De apotheken hebben wel de mogelijkheid om de tekorten aan te pakken via hun personeelsbeleid. Per jaar verlaten ruim 600 assistenten de sector. Slechts een deel van hen gaat met pensioen, de rest gaat of elders werken of stopt helemaal met werken. Het langer vasthouden van personeel is dus een mogelijkheid om de tekorten te verlagen. Daarnaast blijkt dat lang niet alle schoolverlaters met een diploma tot apothekersassistent kiezen voor een baan in de openbare apotheek. Door een groter deel van hen er toe over te halen dat wel te doen zijn de tekorten ook te beperken. Dit kan uiteraard ook gebeuren door de instroom van schoolverlaters te vergroten. De maatregelen die hiervoor nodig zijn, hebben te maken met het aantrekkelijker maken van het beroep zodat de aantrekkingskracht daarvan groter wordt. Hierdoor kan dan worden 
bereikt dat enerzijds de uitstroom afneemt, maar anderzijds de instroom van schoolverlaters en herintreders toeneemt. De verwachte tekorten zijn echter van een zodanige omvang dat er grote veranderingen in de in- en uitstroom nodig zijn om de tekorten volledig op te lossen.

\subsection{Aanbevelingen voor een adequate informatievoorziening}

Naast de uitkomst van de prognoses heeft deze studie ook enkele conclusies opgeleverd ten aanzien van de informatie die nodig is om met enige regelmaat goede prognoses te kunnen maken van de verwachte knelpunten op de arbeidsmarkt voor apothekersassistenten. Daarbij heeft de zeer strikte inperking van het arbeidsmarktsegment - de apothekersassistenten in de openbare apotheek - een aantal voor- en nadelen ten aanzien van de beschikbare en de benodigde data.

Ten aanzien van de gegevens over de aantallen werkenden en gediplomeerden is het door de sterke inperking van het arbeidsmarktsegment mogelijk om zeer nauwkeurig en gedetailleerd gebruik te maken van de beschikbare sectordata (afkomstig van de SPMA). Door deze data kunnen de samenstelling van het personeelsbestand en het verloop daarin zeer goed in kaart gebracht worden. De voor de prognoses noodzakelijke gegevens over de omvang en de samenstelling van de andere groepen moeten echter uit andere databronnen afgeleid worden. Deze databronnen zijn niet gedetailleerd genoeg om harde uitspraken te doen met betrekking tot het aanbod van nieuwkomers en mogelijke herintreders. Het gaat hierbij dan met name om de volgende groepen: de werklozen, de niet-actieven en de gediplomeerde apothekersassistenten die riet in de openbare apotheek werkzaam zijn. Weliswaar kan er op basis van de Enquête Beroepsbevolking (EBB) een indruk verkregen worden van de omvang van deze groepen, maar omdat deze groepen relatief klein zijn is het niet, of slechts in beperkte mate, mogelijk om een goede indruk te krijgen van de samenstelling van deze groepen. Dit houdt in dat hoewel de voor het onderzoek relevante groep van werkzamen in de openbare apotheek zeer nauwkeurig in beeld gebracht kan worden, het moeilijk is om goede gegevens te verkrijgen over het (potentiële) arbeidsaanbod. Dit gebrek aan gegevens kan waarschijnlijk niet of slechts heel moeilijk opgelost worden, zodat ook voor volgende prognoses volstaan zal moeten worden met de informatiebronnen die ook voor het huidige onderzoek gebruikt zijn.

Naast de ontbrekende of slechts in beperkte mate aanwezige gegevens over het arbeidsaanbod is er sprake van een ander hiaat in de beschikbare data. Van vrijwel alle groepen en stromen is het mogelijk om - gegeven de beperkingen van de data - een inschatting te maken van de omvang en de samenstelling naar bijvoorbeeld leeftijd en ervaring. Het is echter niet bekend wat de achterliggende oorzaken zijn van het geobserveerde gedrag. Zo is er bij de schoolverlaters weinig bekend over de vraag of leerlingen zich na (of misschien al tijdens) de opleiding primair richten op een baan in de openbare apotheek. Ook is er niets bekend over de redenen van de (gediplomeerde) schoolverlaters om wel of niet te kiezen voor een baan bij de openbare apotheek. Bij 
de 'inactieven' ontbreekt iedere informatie over de vraag waarom ze ooit gestopt zijn met werken, en of er manieren zijn om hen weer in te kunnen schakelen als apothekersassistent. Het is dus moeilijk om in te schatten welk deel van hen op de arbeidsmarkt zal terugkeren, en in hoeverre daar additionele inspanningen voor nodig zijn. Het is bijvoorbeeld interessant om na te gaan in hoeverre er bij de diverse marktpartijen behoefte is aan om-, her- en bijscholing, en in hoeverre daar al aan wordt deelgenomen. Met name is dit van belang om na te gaan wat de inzetbaarheid is van de 'stille reserve'. Ten slotte is van de werkenden niet bekend in hoeverre zij van plan zijn om werkzaam te blijven als apothekersassistent, en welke factoren deze beslissing kunnen beïnvloeden. Het is voor de prognoses en het daarop gebaseerde beleid nuttig om te weten wat de reden is waarom een betrekking eindigt. Afhankelijk van de reden zijn er immers andere opiossingen te bedenken om het personeel vast te houden in de openbare apotheek. Als men stopt omdat er te weinig carrièremogelijkheden zijn, levert een beleid voor meer kinderopvang niets op. Een dergelijk beleid is echter wel effectief als men voomamelijk stopt met werken vanwege het gebrek aan kinderopvangplaatsen.

Ook over de factoren die de vraag bepalen ontbreekt informatie. Hierbij moet gedacht worden aan gegevens over de samenhang tussen de werkgelegenheid en de vraag naar medicijnen. Voor dit onderzoek is gebruik gemaakt van een vrij strikte lineaire samenhang tussen het aantal recepten en het aantal apothekersassistenten. Het is goed om te weten in hoeverre er bij veranderingen in de vraag ook sprake is van andere aanpassingsprocessen. Hierbij moet vooral gedacht worden aan de samenhang tussen de vraag naar apothekersassistenten en het aantal distributiepunten. Deze samenhang zal zeker van belang zijn als de komende jaren het aantal distributiepunten toe zal nemen als gevolg van de veranderende regelgeving. Verwacht mag bijvoorbeeld worden dat als bij een gegeven groei van het medicijngebruik het aantal distributiepunten meer dan evenredig toeneemt, ook de vraag naar apothekersassistenten sterker zal toenemen dan nu wordt voorzien. Daarnaast zou het nuttig zijn om te weten welke factoren bepalen wie er op een vacature aangenomen wordt: ondanks het feit dat de afgelopen jaren het aantal schoolverlaters groot genoeg leek, zijn er steeds meer ouderen aangenomen, terwijl tegelijkertijd meer schoolverlaters in andere beroepen terecht kwamen.

Het beschikbaar hebben van de hierboven geschetste informatie zal de prognoses kunnen verbeteren. De huidige prognoses zijn gebaseerd op een inschatting van de toekomstige ontwikkelingen van de diverse vraag- en aanbodcomponenten. Er kon hierbij geen rekening gehouden worden met de onderlinge samenhang, en de manier waarop werkgevers en werknemers reageren en anticiperen op de verwachte ontwikkelingen. Als er informatie beschikbaar zou zijn over de wijze waarop werkgevers reageren op vraagveranderingen en knelpunten in de personeelsvoorziening zou dit de kwaliteit van de prognoses kunnen verbeteren. Daamaast zal het in een model dat gebaseerd is op oorzakelijke verbanden ook makkelijker zijn om de effecten van beleidsmatige aanpassingen te kunnen bepalen. 
In dit kader past er hier ook een kanttekening bij de gehanteerde prognosetermijn. Voor het voeren van arbeidsmarktbeleid is een langere termijn noodzakelijk. Het opleiden van apothekersassistenten kost tenslotte tijd, zodat maatregelen die nu genomen worden, pas over een aantal jaren effect kunnen sorteren. Vanuit een technisch oogpunt daarentegen valt er wat voor te zeggen om de termijn niet al te lang te nemen. Er moeten namelijk aannamen gemaakt worden ten aanzien van het arbeidsmarktgedrag van werkgevers en werknemers. Dit gedrag wordt constant verondersteld, maar zal op termijn veranderen. Ook is het nodig om per periode een voorspelling te maken van de omvang en samenstelling van de groep werkenden. Deze voorspelling zal voor perioden die ver weg liggen steeds minder nauwkeurig worden, met als gevolg dat de uitstroomprognoses ook steeds onnauwkeuriger worden. Deze twee technische punten maken dat de prognoses, naarmate ze betrekking hebben op een langere periode, een toenemende mate van onzekerheid krijgen. Het is daarom raadzaam niet verder dan vijf tot tien jaar vooruit te voorspellen, en om de prognoses regelmatig, bijvoorbeeld eens in de twee jaar, aan te passen aan de hand van nieuw beschikbare informatie.

De vraag is dan tot slot hoe de ontbrekende informatie verkregen zou kunnen worden. Hierbij is een aantal mogelijkheden denkbaar. Via de schoolverlatersenquête van het ROA is al iets bekend over de oriëntatie van de gediplomeerde schoolverlaters, maar vanwege de relatief kleine aantallen apothekersassistenten die in deze RUBS-enquête voorkomen, is het moeilijk om echt harde uitspraken te kunnen doen over deze groep. Overwogen zou kunnen worden om de schoolverlaters van de apothekersopleidingen in het kader van de RUBS-enquête integraal te benaderen ${ }^{15}$. Daarbij kunnen ook enkele aanvullende vragen worden gesteld. Deze enquête zou dan met name antwoord moeten geven op de vraag wat voor soort werk deze schoolverlaters zoeken en welke factoren daarop van invloed zijn.

Met betrekking tot de inactieven en de werklozen is er een ander probleem. Juist omdat zij niet werkzaam (meer) zijn, zijn zij moeilijk te bereiken. Een mogelijkheid die denkbaar is, is dat een enquête gehouden wordt onder diegenen die nog voorkomen in het bestand van de SPMA, maar op dit moment niet werkzaam zijn. Het nadeel hiervan is dat iedereen die zijn pensioenrechten heeft ondergebracht bij een ander fonds, of die nooit gewerkt heeft als apothekersassistent buiten dit bestand valt. Dit nadeel doet weinig af aan de voordelen die deze extra informatie oplevert. Deze enquête zou antwoord moeten geven op de vraag waarom men ooit gestopt is met werken en op de vraag of men bereid is weer terug te keren tot het beroep van apothekersassistent, en zo ja, onder welke voorwaarden. Hierbij moet dan met name aandacht besteed worden aan zaken als kinderopvang en de noodzakelijke om-, her- en bijscholing. De laatste groep die ook op basis van de SPMA-gegevens benaderd zou kunnen worden zijn de werkenden zelf. Ook van hen is niet bekend waarom zij ooit gekozen hebben voor een

15. Dergelijke integrale benaderingen vinden momenteel ook plaats bij de leraren- en kunstopleidingen binnen het $\mathrm{HBO}$. 
baan in de openbare apotheek, en wat hun verwachtingen zijn ten aanzien van hun toekomstige loopbaan.

De bovengenoemde drie groepen vormen de werkenden en het potentiële aanbod aan apothekersassistenten. Maar ook over de vraag naar apothekersassistenten ontbreken, zoals reeds werd aangegeven, gegevens: in het verleden heeft de SBA een vacatureenquête gehouden die inzicht gaf in het aantal openstaande vacatures. In plaats van deze informatie is het aan te raden om de apotheken (of een representatief deel van hen) te ondervragen over het personeelsbeleid: wat bepaalt de omvang van de werkgejegenheid voor apothekersassistenten, hoe worden schommelingen in de omzet opgevangen en op welke wijze probeert men in te spelen op knelpunten in de personeelsvoorziening (hierbij kan gedacht worden aan b.v. overwerk, 'op-plussen' van deeltijdaanstellingen, verbeteren van de arbeidsvoonwaarden, om- of bijscholing herintreders). Daarnaast is het ook interessant om na te gaan of apothekers de voorkeur geven aan pas afgestudeerde, onervaren schoolverlaters, of juist aan oudere, mogelijk ervarener, herintreders.

Deze informatie over de vraag naar apothekersassistenten maakt het mogelijk om meer inzicht te krijgen in de werking van de arbeidsmarkt. Dit laatste is ook van groot belang als het prognosemodel gebruikt gaat worden om een aantal beleidsscenario's door te rekenen. De vier genoemde enquêtes onder respectievelijk schoolverlaters, de stille reserve, de werkenden en de werkgevers hoeven overigens niet betrekking te hebben op een integrale benadering van de desbetreffende groep en ook niet jaarlijks herhaald te worden. Gedacht kan worden aan een ondervraging van een representatieve groep waarbij jaarlijks een van de vier enquêtes wordt gehouden. Dit betekent dat de verschillende doelgroepen slechts een keer in de vier jaar benaderd hoeven te worden. Deze opzet voorkomt dat iedereen jaarlijks een enquête in moet vullen, wat naast de hoge kosten, op termijn waarschijnlijk ook tot een relatief grote non-respons leidt. 


\section{Literatuur}

Borghans, L., (1991), 'De arbeidsmarkt en de invloed van voorspellingen', Economisch Statistische Berichten, Vol. 76, no. 3833, blz. 1113-1116.

Borghans, L. en A. de Grip, (1999), De werking van de arbeidsmarkt voor verpleegkundigen en verzorgenden, RVZ/RMO, Zoetermeer/Den Haag.

Borghans, L., J. Delmee, P. Marey en J.D. Vlasblom, (1998), Toekomstverkenning arbeidsmarkt en scholing tot 2007 , Ministerie van Sociale Zaken en Werkgelegenheid, Den Haag.

Centraal Bureau voor de Statistiek, (1997), Nederland in tijdreeksen, Voorburg/Heerlen. Grip, A. de, E.J.T.A. Willems, J. Hoevenberg, P.J.E. van de Loo en A.G.M. Matheeuwsen, (1994), Toekomstverkenning Arbeidsmankt Zorgsector, ROA-R-1994/6, Maastricht.

Grip, A. de, (1988), Scholing en werk, SMO-boek, Den Haag.

Groot, W., (1998), Hebben we genoeg zorg?, Inaugurele rede, Universiteit Maastricht, Maastricht.

Koning, J. de, (1987), Omvang en oorzaken van labour hoarding, proefschrift, Erasmus Universiteit Rotterdam, Rotterdam.

Linssen, J.A.C., (1996), 'Opleiding van apothekersassistenten in beweging', Pharmaceutisch Weekblad, 131(3), p. 83-87.

Management Research Centre Nijenrode, (1993), Als een pil niet helpt, Oorzaker en oplossingen voor het structurele tekort aan apothekersassistenten, Breukelen.

Ministerie van Volksgezondheid, Welziinn en Sport, (1996), Rapportage Arbeidsmarkt Zorgsector 1996, Den Haag.

Researchcentrum voor Onderwijs en Arbeidsmarkt, (1993a), De arbeidsmarkt naar opleiding en beroep tot 1998, ROA-R-1993/10, Maastricht.

Researchcentrum voor Onderwijs en Arbeidsmarkt, (1993b), De arbeidsmarkt naar opleiding en beroep tot 1998, (Statistische Bijlage), ROA-R-1993/10B, Maastricht.

Researchcentrum voor Onderwijs en Arbeidsmarkt, (1997a), De arbeidsmarkt naar opleiding en beroep tot 2002, ROA-R-1997/7, Maastricht.

Researchcentrum voor Onderwijs en Arbeidsmarkt, (1997b), De arbeidsmarkt naar opleiding en beroep tot 2002, (Statistische Bijlage), ROA-R-1997/7B, Maastricht.

Rooij, J.M. van, M.L.N.M. Luyten en P. de Wolf, (1995), Kostenbeheersing, farmaceutische hulp en de werkgelegenheid van apothekersassistenten, Faculteit der Bedrijfskunde, vakgroep Strategie en Omgeving, Erasmus Universiteit Rotterdam. Stichting Bedrijfsfonds Apotheken, (1995), Om de kwaliteit van het werk, Een overzicht van de activiteiten van de Stichting Bedrijfsfonds Apotheken in 1994, Den Haag.

Stichting Bedrijfsfonds Apotheken, (1997), Jaarverslag 1996, Den Haag.

Smoorenburg, M.S.M. van en R.K.W. van der Velden, (1996), Apothekersassistenten, Risico's van een geprofessionaliseerde vakdeelmarkt, OSA-publicatie D3, Den Haag.

Stichting Farmaceutische Kengetallen, (1997), Data en Feiten 1997, Kostenontwikkeling van de farmaceutische hulp, Den Haag 


\section{Literatuur}

Borghans, L., (1991), 'De arbeidsmarkt en de invloed van voorspellingen', Economisch Statistische Berichten, Vol. 76, no. 3833, blz. 1113-1116.

Borghans, L. en A. de Grip, (1999), De werking van de arbeidsmarkt voor verpleegkundigen en verzorgenden, RVZ/RMO, Zoetermeer/Den Haag.

Borghans, L., J. Delmee, P. Marey en J.D. Vlasblom, (1998), Toekomstverkenning arbeidsmarkt en scholing tot 2007, Ministerie van Sociale Zaken en Werkgelegenheid, Den Haag.

Centraal Bureau voor de Statistiek, (1997), Nederland in tijdreeksen, Voorburg/Heerlen. Grip, A. de, E.J.T.A. Willems, J. Hoevenberg, P.J.E. van de Loo en A.G.M. Matheeuwsen, (1994), Toekomstverkenning Arbeidsmarkt Zorgsector, ROA-R-1994/6, Maastricht.

Grip, A. de, (1988), Scholing en werk, SMO-boek, Den Haag.

Groot, W., (1998), Hebben we genoeg zorg?, Inaugurele rede, Universiteit Maastricht, Maastricht.

Koning, J. de, (1987), Omvang en oorzaken van labour hoarding, proefschrift, Erasmus Universiteit Rotterdam, Rotterdam.

Linssen, J.A.C., (1996), 'Opleiding van apothekersassistenten in beweging', Pharmaceutisch Weekblad, 131(3), p. 83-87.

Management Research Centre Nijenrode, (1993), Als een pil niet helpt, Oorzaken en oplossingen voor het structurele tekort aan apothekersassistenten, Breukelen.

Ministerie van Volksgezondheid, Welzijn en Sport, (1996), Rapportage Arbeidsmarkt Zorgsector 1996, Den Haag.

Researchcentrum voor Onderwijs en Arbeidsmarkt, (1993a), De arbeidsmarkt naar opleiding en beroep tot 1998, ROA-R-1993/10, Maastricht.

Researchcentrum voor Onderwijs en Arbeidsmarkt, (1993b), De arbeidsmarkt naar opleiding en beroep tot 1998, (Statistische Bijlage), ROA-R-1993/10B, Maastricht.

Researchcentrum voor Onderwijs en Arbeidsmarkt, (1997a), De arbeidsmarkt naar opleiding en beroep tot 2002, ROA-R-1997/7, Maastricht.

Researchcentrum voor Onderwijs en Arbeidsmarkt, (1997b), De arbeidsmarkt naar opleiding en beroep tot 2002, (Statistische Bijlage), ROA-R-1997/7B, Maastricht.

Rooij, J.M. van, M.L.N.M. Luyten en P. de Wolf, (1995), Kostenbeheersing, farmaceutische hulp en de werkgelegenheid van apothekersassistenten, Faculteit der Bedrijfskunde, vakgroep Strategie en Omgeving, Erasmus Universitelt Rotterdam. Stichting Bedrijfsfonds Apotheken, (1995), Om de kwaliteit van het werk, Een overzicht van de activiteiten van de Stichting Bedrijfsonds Apotheken in 1994, Den Haag.

Stichting Bedrijfsfonds Apotheken, (1997), Jaarvers/ag 1996, Den Haag.

Smoorenburg, M.S.M. van en R.K.W. van der Velden, (1996), Apothekersassistenten, Risico's van een geprofessionaliseerde vakdeelmarkt, OSA-publicatie D3, Den Haag.

Stichting Farmaceutische Kengetallen, (1997), Data en Feiten 1997, Kostenontwikkeling van de farmaceutische huip. Den Haag 
Stichting Farmaceutische Kengetallen, (1998), Data en Feiten 1998, Kostenontwikkeling van de farmaceutische hulp, Den Haag

Vermeulen, H.J.J.M., A.C.M Vissers, K. de Vos en J. Weltevrede, (1998), Prognoses van knelpunten op de arbeidsmarkt van de zorgsector, IVA, Tilburg.

Windt, W. van der, H. Clasbeek en L. Hingstman, (1998), Verpleging en verzorging in kaart gebracht, 1998, NZi/NIVEL, Den Haag.

Wolf, P. de, M.H. Spigt en A.A.T. Overgaag, (1997), De apothekersassistenten in model, Een simulatiemodel voor de prognose van arbeidsplaatsen in de openbare apotheken, Faculteit der Bedriffskunde, vakgroep Strategie en Omgeving, Erasmus Universiteit Rotterdam. 
